\title{
GRUNDTVIGS SALMER OG DERES MELODIER
}

Foredrag ved Grundtvig-Selskabets a a rsmøde 20. oktober 1950.

Af Arthur Arnholtz.

1. SALMEDIGTNING OG SALMESANG. Vore salmemelodier har, som al folkelig sang, to kilder. Dels komponeres de op gennem tiderne af hver periodes professionelle komponister og kommer ved disse større eller mindre bidrag fra fagmændene til at spejle musikens almindelige udvikling. Dels skrives de, eller samles og tilpasses fra yderst brogede kilder, af amatører, især præster og andre salmedigtere med deres mindre sagkyndige venner og raadgivere, og kommer herved til at gaa deres egne veje, bestemt af samlerens smag for det gode eller mindre gode, det gamle eller det nymodens o. s. v. ${ }^{1}$ ).

Ogsaa efter deres funktion falder salmemelodierne $i$ to hovedgrupper. Den ene er den mere objektive og konservative kirkesalme, hvis faste melodistok bevares og respekteres i næsten alle salme- og koralbøger, baade officielle og private, fra Luther til romantiken. Den anden er den mere subjektive og aktuelle aandelige vise, over for hvilken digterne, samlerne og udgiverne har følt sig friere og vist deres personlige musikalske smag.

Begge melodigrupper skifter ganske vist præg fra periode til periode. I første gruppe ændrer tidspræget dog ikke selve melodibestanden, men kun melodiernes form og udsættelse (fra rytmisk til stiv koral, fra vokalmelismer til instrumentalforsiringer, fra kirketonearter til dur-mollsystem). I anden gruppe er det derimod selve melodiskatten, der veksles, som moderne skifter. Det er her, inden for den aandelige vise, at Sthen kan tillade sig at skrive til folkevisemelodier, Kingo til hyrdesange, Brorson til rokokoarier og Ingemann endelig til de musikalske glansbilleder, han fik smag for efter Weyses død (»Dejlig er jorden« og »Glade jul« 1850).

1) Jf. N. Schiørring: „Det 16. og 17. aarhundredes verdslige danske visesang《 1950 , I s. $180-297 ; 391$. 
I rækken af vore salmedigtere, som næsten alle tillige var musikamatører, staar Grundtvig som den eneste helt umusikalske - og samtidig dog som den, der fik baade kirkelige og folkelige kredse til at synge som aldrig før. Det vil være rimeligt først at prøve paa at forklare dette paradoks.

\section{DEN EKSISTENTIELLE SANGS BEGREB. Midt i den} femte »Brage-Snak«-forelæsning ${ }^{2}$ ) bekender Grundtvig: ». . . nu er jeg, til uheld, selv meget umusikalsk«, og ved foredragets slutning

$\left.{ }^{2}\right)$ 1843, tr. 1844. En antydning af, »at ligesom Letos børn udtrykker poesien, saaledes udtrykker Niobes musiken... Alt, hvad jeg her tør sige, er, at lyver Conversations-Lexikonet (som G. har slaaet op i paa 》Tone og Ton-Arter(), saa lyver jeg med, men siger det sandt, da gaar det med tonerne, ligesom med Niobes børn, at man ikke ret veed, om der skal være tolv eller flere $\mathrm{i}$ alt, men at der $\mathrm{i}$ alt fald er ligemange toner i dur og i mol ... saa er Niobe-mythen særdeles skikket til en billedlig fremstilling af den tanke, at musiken maa være saa guddommelig som den vil, saa holder den dog op at være menneskelig, saafremt den foragter poesien, eller ophøier sig over den ..« (»Udv. skr.« v. H. Begtrup, VIII, 1909, s. $553 \mathrm{f}$. og 557).

Om Grundtvigs syn paa musiken i hans tidligere aar, før hans salmedigtning saa at sige tvang ham til beskæftigelse med de enkelte melodier, findes følgende vidnesbyrd, som lektor, dr. Gustav Albeck venligt har gjort mig opmærksom paa:

Som bekendt (se F. Rønning: »N. F. S. Grundtvig« I, 2 (1907), s. $29 \mathrm{ff}$.) begyndte Grundtvig paa »Egelykke« i 1805 en »Udtogsbog«, hvori han dels indskrev og reviderede sine meningsytringer fra de tidligere dagbøger, dels fortsatte med uddrag og kritik af de værker, som siden fængslede ham.

Den 23. 6. 1802 havde han i sin dagbog (Fasc. 498) bemærket: 》Addisons Spectator. 2 dele. Jeg antegner følgende sted, enten fordi det passer paa vor tid, eller fordi jeg ingen musikynder er: Musik er i sig selv en yndig moro, men bliver den saaledes eneherre over vort øre, at vi hindres fra at laane det til noget - Addison føyer ligesaalidt som jeg ordet andet til - klogt og fornuftigt, lykkes det den at fjerne de adle konster og skønne videnskaber, der dog have langt mere kraft til at hæve mennesket, fra os, da er jeg fuldkommen enig med Plato, der forviste den af sin stat. Ey nægter Addison musiken kraft til øieblikkelig at hæve sjælen, thi derved vilde han borttaget den eneste fornuftige tendents - om en saadan gives - den ædle spillekonst har, men reducerer blot hævekraften - som autor - til et minimum.«

Den 11. 7. 1805 føjer han hertil i udtogsbogen (s. $20 \mathrm{ff}$.) : »Siden hin tid har jeg saavel heri som i det meste andet forandret mine tanker. Ey som om jeg nu ikke længere ler hjertelig over musikens dumme forgudere af begge køn, der stræbe at undskylde sin ikke-sands for de mange skønheder, natur, og en med samme i haand gaaende konst har frembragt og 
gentager han: ». . . jeg forstaar mig, som sagt, slet ikke paa musiken«. Omtrent samtidig beklager han sin usikkerhed m. h. t. valg af salmemelodier i brevene til P. Fenger i anledning af »Psalme-blade til kirke-bod« 1843. »Kan De slet ikke sige mig nogen raad til saadanne fire linier: Apostlerne sad i Jerusalem . . skriver han d. 14. marts; »de maatte kunne synges som de første 4 linier af 'Den signede dag, som vi nu seer', men om slig halvveis sang gaaer an, veed jeg ikke.《 Og den 25. s. m. siger han rent ud: »Næst det at kirke-psalmerne skal være indvortes passende, maae de for at være gode til deres brug udvortes (være) lidt mere end blot syngelige, og derom

frembringer med en høj, udelt sands for de modulerede toner. (Herefter et spark til de musikalske klubber med deres krampagtigt interesserede, gabende Københavnerinder).. Ey som om jeg nu henrykkes af de bizarre kompositioner, hvori konsten bestaaer $i$ overdrivelse, eller af en forgudet sangerindes rallende triller. - Ney, alt sligt hensætter mig i den pinlige stilling uophørlig at gabe uden ro til at tænke eller sove.

Men jeg har læst Kofods smukke bog om »Musikens indflydelse paa mennesket« (fra 1804) og deraf lært mange dens veldædige virkninger; jeg har ved lidt nøyere tænken fundet, at dens hylding aldrig kan slappe eller svakke følelsen for de øvrige smagens værdige genstande, men at naar saa synes, er det en blot illusion, fremstaaende deri at individet af en eller anden aarsag hykler en ufølt interesse. Thi hvorlunde skulde den, der trylles af musiken $i$ sin naturlige adle skikkelse, den nemlig naar den enten fremtriner i festlig dragt og med høytidelighedens langsomme fjed byder os ahne en høyere væren, en sig udtalende guddom; eller naar den med blidhedens indtagende aasyn tolker hjertets længsler, de milde, kærlige følelser og deres veemodblandede fryd; eller naar den, hyllet $\mathrm{i}$ graciers klædebon og prydet med krandsen af spøgens uvisnende roser, byder alt blomstre trindt sig og nøder os til at aabne vort hele væsen for den letsvævende glædens gudinde - eller overalt, naar den viser sig i en af de tusinde vekslende gestalter . . hvortil naturens gavmilde aand lagde stof $\mathrm{i}$ dens lyde - hvorlunde kan vel den der henrives af slig musik, haane eller ringeagte dens yndige søstre, de bildende konster og skønne videnskaber? ...

- Dog sandheden tro maa jeg tilstaae, det er ey blot ved nøyere tænken jeg kom did ... Jeg troede at mangle smag for musiken, fordi jeg sammenblandede den med hine vanskabte karikaturer, som falskelig bar dens navn. Men Palmine, af min glædløse drøm vaktes jeg ved din rene ukonstlede stemme. Da hver din tone trængte sig til mit væsens inderste, og langt fra at svakke min sands for naturens ynder blev en glandsfuld punkt $i$ dens krone og fremkaldte enhed og samklang $i$ alle mine følelser - da lærte jeg kraftigere end tusinde beviser, at musiken forædler livet, formindsker sorgen, og gør selv glæden gladere. Fast er min overbevisning, men end fastere, mere omfattende vilde den været, hvis jeg $\mathrm{i}$ tidligere dage havde nydt den lykke at trylles af harmonien mellem din sangs toner og citharens lyde.«

Aaret efter, 1. 10. 1806, sluttede Grundtvig sin afhandling »Om religion 
har jeg ofte kun et svagt og altid kun et dunkelt skiøn $\left.\ll^{3}\right)$. Endelig havde han aaret forinden beklaget sig i sit nytaarsbrev til Inge$\operatorname{mann}^{4}$ ). Efter at have omtalt Peter Rørdam som en fortræffelig forsanger baade for Merns menighed og sogneraad udbryder han: 》Jeg ønsker tit mellem mine konfirmander, at jeg ogsaa kunde tone en salme og en vise; det vilde bringe mere livlighed, end jeg med al min tale kan fremkalde.« Med disse ytringer af Grundtvig selv stemmer en bemærkning af Svend Grundtvigs enke, fru Laura, om hvordan Grundtvig i de unge aar havde undervist sine sønner Johan og Svend hjemme: „Af salmer lærte de en del udenad, men salmesang var der ikke. Det var der vel i det hele taget ikke meget af paa den tid (d.v.s. i 1830-erne), selv i kristelige hjem; og den musikalske ævne var ogsaa kun svag i den Grundtvigske familie $\kappa^{5}$ ). Lidt sang i hjemmet fik Grundtvig dog paa sine ældre dage, omend han næppe selv deltog i den. Om husandagterne i 1860-erne i hans

og liturgi« (tr. i Fallesens »Teologisk maanedsskrift for fædrelandets religionslærere« Febr. 1807; refereret hos Rønning, anf. skr. I, 2, s. 119 -157 , nedenst. stk. s. $141 \mathrm{f}$.). Her strejfer han for første gang salmernes fremførelse: » $\mathrm{Nu}$ komme vi til sangen, middelpunkten af den liturgiske poesie. Her maa alt hvad mennesket kan frembringe (af) højt og skiønt forene sig. Poesien maa træde frem, klædt i det harmoniske vers, hvilende paa det melodiske riim, og hævet ved den potenserende musik. Høit over jorden maa vi opløftes, og et glimt af det evige liv maa svæve forbi vort mod himlen stirrende øie. - Ak! Kun sielden skeer det, og hvad er aarsagen? Er det allene i de kirker, hvor den gamle psalmebog bruges, at vi vorde skuffede $\mathrm{i}$ vor forventning? Ingenlunde. Vi miskiende ikke den nyes fortrin især med hensyn paa korrekthed i versebygningen, og værdighed i udtrykket. Vi tilstaae endog, den indeholder megen poesie, men langt er den fra idealet, der svæver for vort øie. Den kunde laant mere af den gamle, og meget tabte den ved til deels at rette sig efter moralens kapitler . . Bleve imidlertid de nye psalmer udførte, vi ville ei sige ved harmonisk musik; thi det er kun vore katholske brødre der have noget til overs for den(s) skiønneste brug, men ved melodisk sang, da vil der dog allerede meget være giort. Men saalænge mængden af vore kirkers syngemestre endnu kunne lære meget af Bræger og Peer Degn, ville selv de skiønneste psalmer tabe deres kraft, og udbrede dorskhed istedet for dyb følelse.«

$\left.{ }^{3}\right)$ »Breve fra og til N. F. S. Grundtvig« udg. af Georg Christensen og Stener Grundtvig, II, 1926, nr. 461-469 med adskillige bemærkninger ud over de anførte, der viser G.s interesse for at finde passende melodier. Interessantest er vel hans afvisning af »en kæmpevise«, hans tvivl om 》O sanctissima《 (11/3) og hans accept af omkvædet »Roser og yndelige blommer《 til 》Abrahams vise《 $\left({ }^{25} / 3\right)$.

4) Jf. Carl Langballe: »Folkesangen i Danmark « 1944, s. 47.

5) »Minder fra gamle grundtvigske hjem《 I, 1921. Optr. i »Grundtvigs erindringer og erindringer om Grundtvig« 1948, s. 145. 
og fru Astas villa »Gladhjem« paa Gl. kongevej fortæller H. P. B. $\left.\operatorname{Barfod}^{6}\right)$ :

》Saa samledes hele familien hos ham (dvs. i hans arbejdsværelse) til morgenandagt, og i den deltog ogsaa altid folkene. Han bad en kort bøn, bekendte troens ord, bad Fadervor og lyste velsignelsen. Hverken Grundtvig eller fru Asta havde videre sangstemme, derimod sang deres pige Maren godt og gærne, og hun var derfor daglig forsanger. Efter Marens giftermaal overtog den nye pige Nicholine glad og gærne ledelsen af sangen. Som regel begyndte andagten med salmen: 'Som foraarssolen morgenrød stod Jesus op af gravens skød', ofte valgte børnene slutningssalmen. Aftenandagten formede sig paa samme maade, men ved den sluttedes der med 'Sov sødt, barnlille'. S. 46 fortsættes: »Men især om søndagen var huset fuldt af gæster . . Saa afvekslede samtale med sang, og klangen af de mange røster lød langt ud over den ellers saa stille Gl. kongevej. Sangen lededes ikke af noget instrument, thi forunderligt nok fandtes der intet klaver i hjemmet.«

Skønt jeg har faaet god hjælp fra mange sider ${ }^{7}$ ), er det kun lykkedes mig at opdrive disse faa negative vidnesbyrd om Grundtvigs musikalske formaaen. Fraværelsen af alle positive, mangelen paa enhver oplysning om, at Grundtvig selv skulde have sunget med eller messet ved sine gudstjenester, fører Steen Johansen - i et brev til mig af 28. 9. 1950 - til den slutning, »at Grundtvig faktisk ikke sang og ikke kunne synge, og at han heller ikke har »brummet med « paa sine salmer. Hvis han $f$. eks. havde haft den faste vane at »brumme«, vilde en eller anden utvivlsomt have meddelt $\left.\operatorname{det} \ll^{8}\right)$. Steen Johansen har sandsynligvis ret; men da hans slutning er vel dristig, skal jeg for en sikkerheds skyld anføre et par træk om Grundtvigs mundtlige fremførelse, for at hans musiske præg kan være nogenlunde belyst, før vi gaar videre.

Som myndig og øvet prædikant og lærer, foredragsholder og folketaler har Grundtvig uden tvivl raadet over betydelige retoriske evner. Hans talers langtspundne prosa tyder for mig paa et stort aandedrag og en bredt bærende udtrykskraft - over imod den Vilh. Andersen'ske talekunst. Hans talestemme var vel altid dyb og er nok yderligere mørknet $i$ hans alderdom. Pastor Johan Clausen har fortalt mig dette indtryk, som ogsaa stemmer med Edmund

B) »Minder fra gamle grundtvigske hjem《 III, 1923, s. $45 \mathrm{f}$.

$\left.{ }^{7}\right)$ Jeg staar her især i taknemmelighedsgæld til de grundtvigske præster Thorvald Balslev og Johan Clausen og til Grundtvig-forskerne dr. Helge Toldberg og magister Steen Johansen.

8) »Mærkeligt er det at se«, hedder det videre, »at der vistnok aldrig synes at være foregaaet en brevveksling mellem Grundtvig og en eller nogle af hans komponister; der synes overhovedet ikke at være opbevaret f.eks. en taknemmelighedsytring fra Grundtvigs side over en særlig fremragende melodi.« 
Gosse's fra en Gudstjeneste i Vartov 1872, en maaned før Grundtvigs død ${ }^{\theta}$ ):

》Jeg betragtede de mange mærkeligt fanatiske ansigter, saae kvinder sidde vuggende hensunkne $\mathrm{i}$ tavs bøn; da gik der en hvisken gennem rækkerne, Biskoppen vilde næppe kunne komme. Og menigheden gav sig til at synge hans salmer, højt og hurtigt, i et staccato af Skjaldens egen opfindelse; det lignede slet ikke den langsomme sang i statskirkerne.«

\section{Grundtvig kommer alligevel, og Gosse fortsætter:}

»Ind traadte en olding, xldre end alt, hvad jeg havde set af menneskelige væsener. Han gik hurtig hen til alteret. Strax blev der dødsstille i kirken, og man hørte en stemme, der kom som fra kælderen under os. Det var Biskoppen, der bad højt foran alteret; saa vendte han sig om imod os og holdt sin skriftetale med samme dumpe, slørede røst ... han talte uden at bevæge læberne . . Endelig besteg han prædikestolen og begyndte at tale; hans dødningestemme advarede os ... Han talte med stor anstrængelse, mer og mer langsomt og utydeligt, og tilsidst med lange ophold mellem ordene, som et ur der er ved at gaa istaa.«

Alderdomstegnene kan vi her se bort fra; mærkeligst er oplysningen om sangen »i et staccato af Skjaldens egen opfindelse«. Hvad den betyder, og om den skal sammenholdes med Sigurd Müllers ${ }^{10}$ ) angivelse af Grundtvigs »særlige maade at støde ordene frem paa«, er jeg ikke klar over.

Om sin oplæsning af vers har Grundtvig selv, som det var at vente, ingen tekniske bemærkninger gjort. Vi ved, at han efter sin prædiken i Vor Frelsers julemorgen 1825 fremsagde »Velkommen igen, Guds engle smaa《 》med glad og mild røst $\left.\ll^{11}\right)$; og han antyder

9) »To besøg i Danmark 1872-1874«, 1911, overs. af Vald. Rørdam 1912, s. 78 f. - Jf. Morten Pontoppidans omtale af den »dybe stemme« (»N. F. S. Grundtvig som folkelig og kirkelig vækker« $i$ »Vort folk i det nittende aarhundrede«, udg. af Vilh. Østergaard, II, 1901, s. 185).

10) »Grundtvig og formkunsten« $i$ »Tidsskrift« udg. af Holger Begtrup, IV, 1908 , s. 135. - Pastor Johan Clausen, der som 11-aarig hørte Grundtvig i Vartov, mindes dunkelt hans talestemme som »vægtig, magtfuld, stødende. Maaske brummede han med paa sangene.«

11) I »Christelige prædikener eller Søndags-bog « III, 1830 (Prædiken IV: »Advents-nat og jule-morgen«, med motivet: »Vi slide tiden i en adventsnat . « s. 81) hedder det blot til slut (s. 97) : »Kan vi da ikke endnu høirøstet istemme en værdig jule-psalme . . . saa lad os dog barnlig nynne $\mathrm{i}$ den gamle tone (Dagvisens melodi?), ved glimt af julenattens engle . . .«, hvorefter digtet følger.

I tidsskriftet »Danskeren « (udg. af Fr. Nygaard og L. Schrøder, II, 1889 , s. 363-383) meddeler Fr. Nygaard en rakke »Minder om Grundtvigs præstevirksomhed i Kjøbenhavn 1813-15 og 1822-26«. Med to af Grundtvigs tilhørere fra disse aar som kilde (den gamle guldsmed Clausen og den 18-aarige Hanne Ley) berettes her (s. 382) om julemorgenen 1825: »Kirken var propfuld af mennesker. Da Grundtvig kom paa prædikesto- 
selv i forordet til sin Skamlingsbanke-tale $1844^{12}$ ), at han har fremsagt »De snekker mødtes« for studenterne, mens skibet fra København sejlede forbi Odden: »Da stemmede ungdommen op og sang min gamle vise om Villemoes for »piger smaa《 og derved fik jeg den bedste lejlighed til at minde om, hvad der staar paa bautastenen over ham . . Men at hans verslæsning havde sin ejendommelighed, der ikke tiltalte enhver, har vi to vidnesbyrd om. Da han i anledning af Thorvaldsens hjemkomst i 1838 reciterede et eget digt offentligt, faldt det ihvertfald ikke i H. C. Andersens smag: »Da traadte Grundtvig op, men et organ som hans har jeg aldrig før hørt; jeg fnisede! Fru Drevsen var mørkerød i ansigtet, jeg vovede ikke at see paa hende. Gud, hvor jeg loe. Rigtignok var det ikke smukt at være saa lystige $\ll^{13}$ ).

Og om hans deklamation af digtet »Jaordet《 ved en familiefest i 1817 bemærker lægen Carl Otto ${ }^{14}$ ) følgende: 》Jeg tør sige, at kun faa af de tilstedeværende forstod det, da det blev fremsagt paa hans sædvanlige maade: skanderende $\mathrm{i}$ op- og nedgaaende takter, hvad for en stor del betog det dets skønhed.«

Meningen maa vel være, at Grundtvig - som digtere ofte gør for at undgaa en skuespillerisk, prosanær ødelæggelse af versene - for det første har læst ret taktfast, men at han dertil har understreget dette yderligere ved at sige alle stærkstavelserne i højt leje og svagtstavelserne i dybt. Resultatet har da ikke været en blidt melodisk, sammenhængende strøm, men en huggende skandering, som har faaet ekstra tynge af den monopodiske tendens i de fleste Grundtvig-digte, dette, at de fleste versaccenter er fuldvægtige, at den smidigere skiften med halvvægtige accenter mangler. Endelig bruger Grundtvig jo, hyppigere og dristigere end de fleste, tunge stavelser ogsaa paa de lettes pladser i metrene - og har da maaske ogsaa klaret disse konflikter ved brug af kunstige højtoner i sin oplæsning, altsaa f. eks.

len, var der som en forklaret glans over hans aasyn. Han saa lys og glad ud. Men størst var glansen over ham, da han sluttede sin prædiken med at sige, at han i denne julenat havde faaet en ny sang, som han nu vilde meddele. Han fremsagde da med glad og mild røst: 'Velkommen igen Guds engle smaa'.« - Jeg takker dr. Helge Toldberg for henvisningen til denne beretning.

$\left.{ }^{12}\right)$ Udv. skr. v. H. Begtrup, IX, 1909, s. 27.

13) H. C. Andersens brevveksling med Henriette Hanch (Anderseniana IXXIII, s. 274)

14) 》Grundtvigs erindringer . .« 1948, s. 124. Smst. s. 123 hører adjunkt D. P. Smith Grundtvig oplæse »Rosskilde-riim« ved landemodet 1812 og »med sin dybe, monotone stemme så godt som synge det for i en stadig bølgegang.« 


\section{》hos úngmǿen hans tillále« 0.1 .}

Det er utvivlsomt kun med henblik paa disse træk, at Vilh. Andersen $^{15}$ ) skriver: »Grundtvig nynnede ikke som Brorson sine salmer frem til lut, men brummede dem efter rytmen«; om noget egentlig musikalsk er her slet ikke tale. Endelig benytter Grundtvig selv i talrige digte og nu og da ogsaa i prosa udtrykket »nynne«. Under arbejdet paa Sangværkets første bind i sommeren 1835 skriver han til Gunni Busck ude fra Emiliekilde ${ }^{16}$ ): »Derude nynner jeg paa de gamle psalmer, og de klinge saa deiligt i mit øre med det blaa hav og den blaa himmel for øie.« Og i det allerede nævnte brev (af 14. 3. 1843) til P. Fenger siger han om et vers af Kingos »Hvor stor er dog den glæde«: »Det har jeg nu saamange aar nynnet paa baade for mig selv og med mine børn, som det staar hos Hagen $\left.\kappa^{17}\right)$. Meningen er sikkert heller ikke her noget musikalsk, men noget poetisk, snart at tilegne sig et digt, snart at sige det for sig selv med den indre stemme.

Vender vi nu tilbage til vort udgangspunkt og spørger: Hvordan kunde denne mand, som var saa fremmed for al egentlig musik, blive vort folks største vækker til sang, saa bliver den forste forklaring vel følgende: Grundtvig gav os den fylde af tekster, uden hvilken vi nu hverken kan forestille os vort kirkelige eller folkelige liv. De synes os saa uundværlige, at de dengang maa have imødekommet et behov. Han kunde trygt lade andre om resten; melodierne skulde nok komme. Denne forklaring er dog for summarisk, for lidt nuancerende og for lidt positiv. Vel var Grundtvig umusikalsk $i$ strengere forstand; men - og her kommer paradokset - han synes i sjælden grad at have bevaret oplysningstidens blik for sangens folkeopdragende betydning.

Fra 1789 arbejdede den saakaldte 》store skolekommission« med planer til vort skolevæsens forbedring. Fra kommissionen anmodede man lederen af Det kongelige kapel J. A. P. Schulz, skaberen af de nye »Lieder im Volkston«, om at berette om sit indtryk af den musikalske tilstand i Danmark, og denne udsendte da i 1790 sit lille, epokegørende skrift: »Tanker over musikens indflydelse paa et folks dannelse og sammes indførelse i skolerne i de kgl. danske stater.« Selve beretningen om folkets ukultur og det konkrete kultiveringsforslag maa her forbigaas. Interessantest, og afgørende for os,

15) »Ill. da. lit. hist.《 III, 1924, s. 185.

18) H. Bech: »Gunni Busck« $1878^{2}$, s. 174 .

17) Mening: i den form, det har i L. C. Hagens »Hist. psalmer og riim« 1832, nr. 20. 
er Schulz's tilføjelse om musikens hensigtsmæssige benyttelse. Musik i utide bør omgaas med maade, da den let foraarsager tidsspilde, kedsomhed eller blot underholdning. "Men musik, der foranlediges ved os selv, og hvis indhold har direkte hensigt paa os selv, paa vor stand, vore følelser, vore huslige saavelsom almindelige glæder og lidelser, - som muntrer, trøster . . . danner, bereder og befordrer vore hjerters og karakterers moralitet - kun denne musik « til rette tid og anledning kan virke forædlende. Og saa efterlyser Schulz en lærebog om dette, hidtil upaaagtede, men folkeligt set allervigtigste forhold, altsaa om skabelsen og benyttelsen af en bekendelsesog oplevelsessang til forskel fra den artistisk-æstetiske kunstmusik.

Med denne smukke idé naaede oplysningstiden selv dog kun i bredden, ikke i dybden. Bøger tilvirkedes med flid - med sange om alt (fra Gud og stjernerne til mennesket og det mindste kryb) og for alle (den gode og renlige kone, den lykkelige bonde, tjenestefolk, sømænd, landsoldater $\mathrm{m}$. fl.). Men det blev jo først af det 19. aarhundredes religiøse og nationale vejr, at folkeligheden groede $^{18}$ ).

Om Grundtvig har faaet begrebet om, hvad vi maaske tør kalde »den eksistentielle sang direkte fra Schulz og hans eftermænd i skolesangsarbejdet $\mathrm{H}$. O. C. Zinck og A. P. Berggreen, eller om han udvikler det paa egen haand i mindet om sin barnepige Malenes sang $\left.{ }^{19}\right)$, ved jeg ikke. Men at den samme tanke har staaet ham klar,

18) Kai Aage Bruun: „Grundtvig og musiken« (Nationaltidendes kronik 27. og 28. maj 1942). - A. Arnholtz: »Folkelig kunstsang i Danmark《 (Danmarks sanglærerforenings aarsberetning f. 1947, s. 42 f.). - Karl Clausen: 》Folkelig sang i Danmark« (Om musik, 1948, s. $130 \mathrm{ff}$.).

19) »Malene Jensdatter fra Grumløse, der aad naadsensbrød i præstegaarden og fra sin krog havde indseende med børnene« (Vilh. Andersen: »Ill. da. lit. hist.« III, 1924, s. 143.) mindes Grundtvig som sin 》Sprogmesterinde« og første salmesyngerske i »Nyaarsmorgen« (1824, IX, 19-27) og tilføjer i »Glarøjne til Nyaars-morgen « (I H. Begtrups udg. af digtet s. $21 \mathrm{ff}$.$) : \gg$ Magdalene eller, paa godt sællandsk, Malene, saaledes hed virkelig vor gamle, vanføre barnepige, hvem jeg skylder den lave, men grunddybe, danske salmetone, der i førnævnte (d.v.s. i digtet nævnte) »O Jesu, for din pine« og nogle andre, stemmer, $i$ den gamle salmebog (d.v.s. Kingos), besynderlig med Kingos højtidelige koraler.« (cit. eft. Uffe Hansen: »Grundtvigs salmedigtning《 1937, s. 7 ff.).

En indirekte værdsættelse af Schulz (som dog ikke selv nævnes) tør man vel se i Grundtvigs berømmelse af »Høstgildet《 i den 4. »Mands minde «-forelæsning (27.6.1838. Sv. Grundtvigs udg. 1877, s. 47 ff., »Værker i udv.« v. Georg Christensen og Hal Koch, IV, 1943, s. 255), hvor det hedder: "Jeg tør paastaa, Danmark vilde føle sig ti gange saa lykkelig som nu . . naar blot alle de dejlige, nydanske viser, der mylrede frem, fra Thaarups Høstgilde til Ingemanns Holger Danske, ikke blot som nu 
fremgaar af hans indstilling til Chr. VIII »Om indretningen af Sorø akademi til en folkelig højskole« (1843). Her hedder det:

»Een lærer i det mindste maatte der være, som kendte og elskede folkesangen baade i dens ældre og nyere skikkelse, og som enten selv kunde være forsanger eller havde dog en fast medhjælper, som kunde være det, thi skønt man lige saa lidt maa lægge an paa at danne hele ungdommen til kunstsangere som til lærde, saa er dog folkesangen, naturligt benyttet, fra arildstid det frugtbare dannelsesmiddel, og maa spille en hovedrolle, hvor ungdommen skal være og lære med lyst.«

Tanken er den samme som hos Schulz. Men hvad han endnu kun realiserede med følelse og finhed i borgerlig begrænsning, virkeliggjorde Grundtvig med fantasi og styrke som sange for et folk. Tiden var moden, og manden var kommet, som vidste og vilde, at der skulde synges. Den Grundtvig'ske sangs problematik blev da, at tekstrealisationen $\mathrm{i}$ al sin storhed og særhed stod alene. Jeg skal skitsere dens møde med en musikalsk samtid og eftertid, som hver søgte at yde den sit.

3. GRUNDTVIG-TEKSTERNES SANGBARHED. Lad os begynde med at spørge, om de tekster, som Grundtvig stillede sin tids komponister, præster, lærere og forsamlinger overfor, var egnede til sang. Den almindelige, æstetiske analyse af det mægtige stof maa jeg her nøjes med at antyde i største nødtørftighed. For en overfladisk betragtning synes det let at overse den Grundtvig'ske salmedigtnings æstetiske betydning paa godt og ondt. Dens blanding af fyndigt og udtværet, ophøjet og plat, ubesværet simpelhed og kejtet dunkelhed stikker i øjnene. Ligeledes dens »to kvaliteter«, de stykker, Grundtvig »fik«, og dem, han blot »lavede«, og dens »to toner«, den sjældnere, men sædvanlig vellykkede »milde«, og den gængse »stærke« med dens stort ansatte diktion og robuste verskunst (den allerede nævnte, overvejende monopodi, altsaa lige stærke tryk selv i sammensatte ord, og de stedvis mere end dristige trykskifter). Naar man kun hertil, vil man synes, at Grundtvig hverken ejer Kingos primitivt prægtige helstøbthed eller Brorsons hemmeligt hjertegribende udtryksfuldhed. Men der er et stykke vej endnu; den æstetiske tilegnelse af Grundtvigs kunst synes stadig uafsluttet. Grunden hertil er, foruden produktionens omfang og mangfoldighed, at hans kunst i dybeste forstand er »anvendt《: I det højeste formaals tjene-

stod paa papiret, enten aldrig sungne eller dog kun en gang til stads eller en vinter $\mathbf{i}$ hovedstaden, men havde gjenlydt $i$ alle vore skoler og derfor naturligvis ikke blot $\mathrm{i}$ alle vore marker og skove, men saa vidt Danebrog vajede paa det sortladne hav.« 
ste, i kampen for at udtrykke den verden af aand, som blev hans, finder den former og naar ud paa dybder, som ikke kendtes før. Det er her mindre udtrykkene for det kendte, som forædles; det er udtrykkene for det ukendte, som fødes. Og heri er ogsaa æstetisk nyskabelse.

Efter indholdet vil vi kalde de tekster sangbare ${ }^{20}$ ), som kan yde en god psykisk baggrund for toneudfoldelse, de, som det føles rimeligt at løfte ud af hverdagen og fremføre med hævet udtryk, syngende, ikke almindeligt talende. Sangbart i denne forstand er ethvert umiddelbart gribende bevidsthedsindhold, det direkte sansede og følte og det, som kan anskues som et hele. Usangbart er derimod det neutralt-logiske, det prosaisk-analytiske, det springende. Grundtvigsalmerne er jo efter deres emner sangbare. Kun en sjælden gang, som $\mathrm{f}$. eks. $\mathrm{i} \gg \mathrm{Kjender} \mathrm{du}$ de gamle salmer ${ }^{21}$ ), synes det diskursive mig at tage overhaand over det intuitive, saa at emnets udformning i Kingos passionsstrofe virker forfejlet og snurrig, selv om dette maaske er en tilsigtet illustration.

Efter udtrykket kalder vi de tekster sangbare, som viser et vist middelmaal af selvstændighed. Det helt udtryksløse rimeri paa hjerte og smerte bliver kun en arietekst, der overlader alt udtryk til musiken, ikke en rigtig sang. Og det alt for selvstændige, digtet, der taler for sig selv, kan det være svært at komponere, umuligt at faa til at »synge«. Her kan det sprog, Grundtvig benytter til at skildre sine nye erfaringer, nu og da volde besvær. Det er ikke saa meget det dunkle som det anstrengte og tætpakkede og hangen til ordspil og brandere, som afstedkommer usangbare passager. Det, som kræver punktuel fremhævelse ved en pludselig tonefaldsændring, vil jo altid forstyrre de jævne, sprogmelodiske kurver, som bedst forenes med sang. Men jo højere inspireret hans digte er, jo mere svinder gerne disse pletter.

Efter formen kalder vi endelig de tekster sangbare, som ved disposition og formtræk selv imødekommer og letter sangkompositionen. Her møder vi atter Grundtvigs paradoks. Naar man ser, hvordan umusikalske digtere ellers gerne knækker halsen, hvergang de skal skrive til et melodiforlæg - tænk blot paa alle de afmægtige tekstforsøg, som knuses af »Kong Christian«-melodien - maa man forbavses over det klarsyn for det sanglige, hvormed Grundtvig bygger sine bedste salmer op.

20) A. Arnholtz: »Det sangbares problem« (Da. musiktidsskrift. 1949, s. 151 $-161)$.

21) 》Sang-Værk« (Gl. udg., i alle flg. angivelser forkortet: SV.) V. 21. 
Grundtvigs verskunst er moderat $\mathrm{i}$ den forstand, at han ikke som Brorson og Ingemann eksperimenterer sig frem til mange nye former selv. Baade rokokoens ariemetre og romantikens mange varianter af Nibelungenverset (som vi især kender dem fra Chr. Winther) har sikkert været ham for flygtige, for fremmede for hans vægtige diktion. Fra folkeviserne tager han ogsaa kun strofeformerne; men han fylder dem ofte fast, enten med lutter 2- eller med lutter 3-stavelsesgrupper. En særlig variant skaber han her i en række af de bibelhistoriske viser ${ }^{22}$ ). I de 4-liniede folkeviseagtige strofer fylder han pausen efter 1. og 3. linie ud, saa de ligesom gaar sammen med 2. og 4. til to langlinier (SV. II, 47, 2):

》Da kom der bud fra min fader som bedst:

'Skynd dig hjem! klæd dig paa! kom til gilde!

Seeren siger, der fattes en gjast,

Det er dig, kom nu ikke for silde!'«

Egentlig musiknære vers, som først bliver et metrisk hele, naar melodien kommer til, bruger han ret sparsomt. De kendteste er 》Julen har englelyd«, »Glæden hun er født i dag«, »Af højheden oprunden er《 og 》Vær velkommen, Herrens aar«. 》I Jesu navn« berører han kun et par gange (SV. IV, 107 og 240) og undgaar, saa vidt jeg ser, helt 》Sions vægter«. Endelig spiller hans norrøniserende forsøg (fra »Bjarkemaalet« 1817) jo ikke nogen væsentlig rolle for hans egentlige salmedigtning ${ }^{23}$ ).

Til gengæld bruger Grundtvig særdeles mange af dem, vi vil kalde centrale salmestrofer, dels de traditionelle $e^{23 b}$ ), dels i varianter, som han selv laver sig ved at tilføje eller udelade stavelser eller linier. Hermed satte han organister og andre sangledere $i$ adskillig forlegenhed. Det pudsigste udslag er nok den medfart, de i deres kvide gav »Paa Jerusalem det ny« (1837). Strofen forekommer os jo ikke indviklet. Den er ligesom den lange række efter »Forfærdes ej, du lille hob«, blot trokæisk i st. f. jambisk; Grundtvig har jo i det hele

$\left.{ }^{22}\right)$ SV. II, 13: »Sara var død«, 14: »Esau var en skytte vild«, 16: »Solen er hed«, 26: »Farao sidder i højeloftssal«, 28: »Kom, lad os synge VorHerre en sang«, 34: »Moses var gammel«, 39: 》Jeriko var en stad saa fast《, 40: 》Josva med arken«, 42: »Midianiten, som en tyrk«, 47: 》Jeg gik i marken og vogtede faar « m. fl.

${ }^{23}$ ) Det kan vist omtvistes, hvorvidt »Hyggelig, rolig« og »Sov sødt, barnlille« er norrønt eller pietistisk prægede.

23b) Iflg. Steen Johansens Grundtvig-bibliografi (II, s. 247) opgav saaledes Peter Rørdam versemaalet til »Nu falmer skoven trindt om land«. 
en ejendommelig forkærlighed for dalende rytmer $^{24}$ ). Da nu Berggreen skulde lave sin melodisamling til Roskilde konvents salmebog, frygtede »man« (det maa være Berggreen selv, Roskilde præstekonvent og Ingemann) at forvirre menighederne med alt for mange nye melodier. Man valgte da den bagvendte vej at jambificere teksten til en af de kendte toner:

\author{
»Paa Guds Jerusalem, det ny, \\ Paa hans, den store konges by \\ Skal hver en christen bygge, \\ Med Herrens aand og med Guds søn \\ Alt under sang og suk og bøn, \\ I Herrens vingers skygge.«
}

Man forstaar Berggreens bemærkning ${ }^{25}$ ): 》Jeg kan imidlertid hverken tilegne mig æren eller paatage mig ansvaret for den maade, hvorpaa forandringen er udført, « - man spørger, hvordan den fintmærkende Ingemann som tilsynsførende kunde lade dette passere; og især beklager man ikke at vide noget om Grundtvigs egen reaktion i dette oplagte tilfælde ${ }^{25 b}$ ).

Paa to punkter naar Grundtvig særlig højt i den sangbare versteknik. Det er i opfattelsen af den folkelige sang som strofisk og i evnen til at disponere til stigning og forenkle til monumentalitet.

For at gøre det rimeligt at synge den ene tekststrofe efter den anden til den samme, stadig genkommende melodistrofe vil den skønsomme sangdigter $\mathrm{f}$. eks. anbringe de rytmiske særtræk hver gang paa samme sted i strofen. Ingemann og Grundtvig benytter

$\left.{ }^{24}\right)$ Dette træk maa her forbigaas, men fortjente en selvstændig undersøgelse. - Jf. E. v. d. Recke: »Principerne f. d. da. verskunst《 1881, II, s. 167, note 1. Og C. Rosenberg: „To nordiske versarter« (Nord. tidskr. . . utg. av Letterstedtska Föreningen, Sthm. 1883, s. 509 ff.).

${ }^{25}$ ) A. P. Berggreen: »Om menighedssangen «, indl. t. hans koralbog 1853 , s. XX. Den udpegede melodi er koralbogens nr. 124 b (»O gode Gud, jeg takker dig« el. »Op, glædes alle, glædes nu«). Den vansirede tekst i Rosk. konvents salmebog 1855 , nr. 284.

25b) Om hans reaktion $i$ almindelighed til Konvents-salmebogens ændringer i hans salmer fortæller pastor Ludvig Hertel (Da. kirketidende 7.3.1886, sp. 150) : »En aften i vinteren i $1864-65$ førte ... højskoleforstander Trier nogle unge studenter, hvoriblandt ogsaa jeg var, ud til Grundtvig. Talen faldt da paa vore forskjellige salmebøger, men klart husker jeg kun en af hans udtalelser; den var omtrent saalydende: 'Der maa være en salmedigter til her i landet, der hedder N. F. S. Grundtvig. Ja, jeg kjender ikke manden, men det maa være ham, der har faaet salmer optaget i Konventssalmebogen, af mig er de ikke.'« - Jeg takker magister Steen Johansen for henvisningen til denne ytring. 
denne teknik, den første i f. eks. morgen- og aftensangene ${ }^{28}$ ), den anden bl. a. $i$ »Kirken den er et gammelt hus og i den lange række evangelie-salmer til dennes melodi ${ }^{27}$ ). To- og trestavelses »fødder《 skifter her, dog ikke tilfældigt, men $\mathrm{i}$ en fast orden, der overholdes fra strofe til strofe. Alle første-, tredie-, femte- og sjettelinier har saaledes en daktyl paa førstepladsen og trokæer for resten:

1, 1: Kirken den er et gammelt hus,

2, 1: Herren vor Gud vist ej bebor,

3,1: Vi er hans hus og kirke nu, o. s. v.,

mens alle anden-, fjerde- og syvendelinier har lutter daktyler:

1, 2: Staar, omend taarnene falde,

2, 2: Huse, som hænder kan bygge,

3,2: Bygget af levende stene, o.s.v.

Herved bevares sangtekstens levende rytmik, samtidig med at den kan følge melodiens toneskridt, spaltede og uspaltede, ens (syllabisk) gennem alle strofer.

Til belysning af Grundtvigs evne til disposition af strofernes helhed maa det være nok at pege paa den skønne kurve $i$ en sang som »Nu falmer skoven trindt om land«. Det er let nok at dele denne salme op i led. Men det æstetisk positive er ikke mindst disse leds forbavsende sammenhæng. Det første (str. 1-3) bevæger sig fra naturindgangen til billedet af Guds jordiske gaver til os. Det andet (str. 4-6) fører os fra takken for høsten til tanken paa Guds omsorg for os. Det tredie (str. 7-8) fra det vakte evighedshaab til synet af Guds fred. Og endelig kan sangen slutte (str. 9-10) med takken for høsten $i$ en forklaret gentagelse under »Hans Aand«s velsignelse. Man finder næppe noget simplere eksempel paa inspireret flugt. Med alle sine levende verber (falmer, daler, flyver, bølged) bevæger digtet sig, strømmer og drager den syngende frydefuldt med sig. Billeder og tanker trænges ikke, som ellers tit hos Grundtvig, men stiger i stille, høstlig klarhed. Ogsaa denne umiddelbarhed og enhed er sangbar; de ti strofer er sunget, før man ved af det.

${ }^{26}$ ) Se gennemgangen af $\gg I$ fjerne kirketaarne hist《, i min afh. »Det sangbares problem « (Da. musiktidsskrift 1949, s. 155).

27) 》Festsalmer« 18567, nr. 756-826: 70 evangeliesalmer fra advent og aaret igennem. - Tekniken forekommer talrige andre steder hos Grundtvig, vel kulminerende i »Modermaalet «s udtryksfulde originalstrofe, der forbinder dette træk med bibelvisemaneren, omtalt s. 18 . 
En anden musikalsk virkende disposition viser $f$. eks. hans nyskabelse af »Et barn er født i Bethlehem«. Den gamle salme hos Thomissøn strider sig tørt belærende frem:
»Hand fødis aff en jomfru sker,
Foruden mand hans fødzel er.
Vort kiød oc blod hand paa sig tog,
Wskad aff Dieffuelen bleff hand dog.
I kiød oc blod er hand oss lig,
I synden er hand oss wlig «

o.s.v.

Fra dette forbillede omstøber Grundtvig beretningen om den første jul med romantikens simpelhed i udtrykket for det underfulde:

»En fattig jomfru sad i løn

Og fødte himlens kongesøn.«

Men derefter slipper han forbilledet og skifter om fra folkelig til barnlig stil. I stedet for at belære ved at binde tankerne lader han dem flyve . . . til julen i »Himmelby«, Guds eget hjem, men med klang som et landsbynavn:

»Paa stjernetæpper lyseblaa

Skal glade vi til kirke gaa.«

Stilskiftet her virker ikke saa meget paa forstanden; det bringer ingen egentlig sammenfatning eller forklaring. Snarere virker det som et registerskifte paa orgelet. Der tilføres digtet en ny sødme, der atter drager de syngende med, indtil sangen hæver sig til den afsluttende tak.

Den monumentale sangbarhed naar Grundtvig endelig gennem sin omkvædsteknik. Hans kærlighed til folkevisen kan faa ham til at overtage dens mellem- og omkvæd ganske naivt og uformidlet. 》Roser og yndelige blommer«, hedder det $\mathrm{i}$ et brev til P. Fenger (25.-3. 1843), »skulde man altid synge med til Abrahams vise, naar der hører omkvæd til tonen, thi et bedre kunde den neppe faae«. Fra dette stade hæver han sig imidlertid gennem imiterende og frit opfundne omkvæd helt op til de mærkeligt slidstærke gentagelsesdele, vi møder i hans bedste liturgiske salmer. Det er sange af typen »O du Guds lam《 (1837) og »Krist stod op af døde«. Til den sidste er forbilledet i vore reformationssalmebøger en enkelt strofe, beregnet til at synges tre gange som et menighedssvar. Først i de »Udkaarne psalmer«, 1642 , oversættes 2 . og 3. strofe, som i det 15 . aarhundredes Tyskland var føjet til den gamle 12. aarhundredes lejse. Grundtvig 
sysler med disse forbilleder lige fra $1815^{28}$ ). Gennem 30 aar gendigter han de gamle vers fire gange, først simpelt regulerende (1815, SV. V, 98. 1837, SV. I, 286), saa med et svagt tilløb til maalet (1843, SV. V, 149: Den skiftende rytmekarakter i de to første linier) og endelig med den store inspiration og kunnen (1845, SV. III, 176). Det gamle responsoriums trefoldige lovprisning er her bevaret med simpel genialitet: Førstelinien er i alle strofer det ens, centrale forløsningsbudskab. Andenlinien varierer det vundne: Efter $\gg I$ paaskemorgenrøde« hedder det her »Afsonet er vor brøde« og »I himlen vi ham møde«. Og derefter udtrykker resten omkvædsagtigt vor tak. Den gamle stammen er blevet en paaskelovsang - uden argumentation eller refleksion, saa betaget af forløsningens kerne, underet selv, at sangen, skønt den kun ændrer een linie pr. strofe, ikke føles stillestaaende, men strømmende og gribende med særlig magt.

Hvad jeg her har antydet om Grundtvig-teksternes sangbarhed, kalder den ensidige æstetiker »finheder«. Udtrykket vilde næppe hue Grundtvig selv. Finheder eller manglende finheder er jo kun krusninger paa overfladen af hans forkyndelses strøm. I dybet nedenunder udvikles hans salmebegreb - fra E. M. Arndts »Bibel in Liedern $\left(^{28}\right)$ til synerne af Gudsrigets kamp og sejr gennem tiderne og Gudsfolkets fælles lovsang ${ }^{30}$ ). Her fuldendes ogsaa hans eget lange løb som menneske og Herrens tjener i den mangfoldighed, som ogsaa kom til at præge hans sang. Man maa undskylde hans tid, ikke mindst hans musikalske samtid, at den ikke skelnede klart mellem guld og slagger. Den kunde jo, af gode grunde, endnu ikke overskue den mægtige strøm.

4. DET TRADITIONELLE MELODISTOF. Fra sin præstegerning har Grundtvig kendt den faste stok af egentlige gudstjenestemelodier, som kirken væsentlig indførte med reformationen, øgede moderat i de følgende aarhundreder og bevarede i praksis og koralbøger op til hans tid. Hvor Grundtvig søger at virke kirkeligt med sine salmer, holder han sig først og fremmest til dem. I første bind af Sangværket (1837) lægger han kun tekster frem uden melodi-

${ }^{28}$ ) Om hans stundom meget bevidste kunstneriske formning jf. tillige Gust. Albeck: 》Grundtvigs Villemoesdigtning « (Fem danske studier tilegnet Vilh. Andersen, 1934, s. 5 ff.) og 》Indskriften paa Oddens mindestøtte《 (Grundtvig-studier 1948, s. $32 \mathrm{ff}$.).

$\left.{ }^{29}\right)$ Jf. E. M. Arndt: »Vom Wort und vom Kirchenlied« 1819, Grundtvigs fortale til »Dejlig er den himmel blaa《 (Sandsigeren 10.4.1811) og hans prædiken om julesalmen (Søndagsbogen II, 1828).

30) Edv. Lehmann: »Grundtvig« 1929, s. 216. 
angivelser ${ }^{30 \mathrm{~b}}$ ); men i de praktiske udgaver, han medvirkede ved, er det kirkeligt-konservative melodisynspunkt nummer eet. I L. C. Hagens »Historiske psalmer og riim til børne-lærdom « (1832) ${ }^{31}$ ) staar saaledes »Far, verden, farvel« (til »O, dejlige land«) som den eneste melodi med stærkere verdslig smag. I de første 7 oplag af »Festpsalmer $\left.{ }^{32}\right)$ er det samme tilfældet. Af egentlig verdslige melodier møder vi her kun atter »Far, verden, farvel« (til »O, christelighed 1854), »Abraham sad i Mamrelund«, formodentlig en folkevise ${ }^{33}$ ) (til »Apostlene sad i Jerusalem《 1851, »Herren han har besøgt sit folk« 1854, o.fl.) og den italienske »O sanctissima«, der trods Grundtvigs berettigede tvivl ${ }^{34}$ ) er sat baade til »Kirken er som himmerige« (1851) og 》Midt iblandt os er Guds rige« m. fl. (1854). Fra 8. oplag (1864) synes en ny melodiredaktør at være traadt til. Her er melodiangivelserne gennemført, hvor de før kun stod spredt; nye er kommet paa fra begyndelsen. Kompositionerne er kommet, saa f. eks. »Vær velkommen, Herrens aar《, »Julen har englelyd《 og »Velkommen igen« kan faa »Egen tone«, og »O sanctissima《 er udgaaet.

Grundtvigs brug af dette traditionelle kirkemelodistof giver ikke anledning til større spekulationer. Han benytter uden ensidighed baade ældre og yngre melodier fra reformationens til pietismens, og baade de simpleste, folkevisenære som »Jeg ved et evigt himmerig«, »Jesu søde hukommelse o. fl., de mellemste som Hildebrand-strofen og »Guds godhed《-varianten, og endelig de store kunstfærdige, »Vor Gud han er saa fast en borg« og »Af højheden oprunden er«. Skulde man udpege nogen som hans yndlingsstrofer, maatte det vel blive 》Jesu, dine dybe vunder« (som Kingo havde brugt til sine passions-

${ }^{30 b}$ Kun to salmemelodier figurerer over nr. 15 og 18 i SV. I, 1837 og $1868^{2}$.

31) Forord om Grundtvigs tekstredaktioner; intet om melodier; adskillige digte uden melodiangivelse, formodentlig til udenadslære.

$\left.{ }^{32}\right) 1850^{1-2}, 1851^{3}, 1852^{4}, 1853^{5}, 1854^{6}, 1856^{7}$. Helt nøjagtig indtræeder den ovenomtalte ændring fra og med tillægget til 7. udg. (fra s. 219); her begynder de angivelser af »Egen melodi《, som gennemføres i 8. udg. 1864.

${ }^{33}$ ) Jf. s. 10 , note 3 , og s. 21.

$\left.{ }^{34}\right)$ Jf. brev til P. Fenger 11.3.1843: »Hvad jeg bad om, var en liste paa andre gamle (salmer), som huede og paa dem i Sangværket, De havde fundet tone til og lyst til at synge. Idag fik jeg endelig Rordams liste, hvorpaa der findes en heel deel af de sidste, men tit staar der enten slet ikke paa hvad melodi, eller jeg henvises til en kæmpevise, der kan være godt nok, men er dog her (til Kirke-bods-salmerne) ubrugeligt. Deres henvisning til »sanctissima《 ved »Kirken er som himmerige«, siger vel Theodor er ganske efterrettelig, men Bojsen kunde dog ikke synge den derefter, saa der maa dog nok giøres lidt forandring derved, ikke enhver falder paa.« - Endnu 5.-udgaven af, Berggreens koralbog (1875) bevarer 》Sanctis-

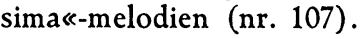


salmer) og den selvgjorte »Kirken den er et gammelt hus«, begge typisk nok i dalende rytmer. Om Grundtvig har kendt den gamle dagvises melodi, vides $\mathrm{ikke}^{35}$ ). Mod hans nydigtning til tusindaarsfesten 1826 udtalte biskop Münter: »Den første har ikke engang en bekendt melodi ${ }^{38}$ ), og fra 1832 (hos Hagen) figurerer Weyses »Den signede dag med fryd vi ser som melodiangivelse til »Velkommen igen «. Dog bruger baade Grundtvig selv og J. C. Lindberg ${ }^{37}$ ) endnu i 1843 melodibetegnelsen »Den signede dag, som vi nu seer«, formodentlig dog blot efter »Sang-Værk« I, 1837, hvor Grundtvig havde givet sit digt denne ændrede førstelinie. Dunkelt er ogsaa Grundtvigs forhold til en anden skøn og betydningsfuld, gammel melodi, nemlig »Krist stod op af døde $\ll^{38}$ ). Skønt Grundtvig næppe har kendt den, benytter han den strofeform, han i 1845 var naaet frem til, allerede i 1851 (i Fest-psalmernes 3. opl.) til fire nye forsøg, alle med »Christ stod op af døde« som melodiangivelse ${ }^{39}$ ). Først 1852 og 1853 kom Berggreens og Rungs melodier.

Ved siden af de gamle kirkesange kendte og elskede Grundtvig vore kæmpeviser. Han bidrog som bekendt selv til 40-ernes folkevisebegejstring ved at udsende en samling af $\operatorname{dem}^{40}$ ). Hans stilling til dem som melodiforlæg synes - efter brevene til P. Fenger - at være den, at som melodier til egentlige kirkesalmer burde de undgaas, men som mønstre for historiske (herunder bibelhistoriske) og aandelige viser var de fortræffelige til efterligning. Hvilke folkemelodier Grundtvig selv har kendt, er vi atter her i uvished om $^{41}$ ). Vi kan kun udpege nogle sange, hvis indhold, holdning, førstestrofe eller omkvæd, maaske ogsaa form og melodi, øjensynlig har inspireret ham. Til de mange 4-liniede strofer kan næppe bestemte forbilleder fixeres. Det kan have været »Elverhøj«, »Dronning Dagmar«, »Hr. Zinklar«, »Der vanker en ridder« eller mange andre, som Lindberg faktisk anfører ${ }^{42}$ ); en enkelt af dem, »Svend Vonved《 til

${ }^{35}$ ) Den stod hos Thomissøn 1569 og Arrebo 1627, men optryktes derefter først i Th. Laubs »Om kirkesangen« 1887.

38) I »Høitids-psalmerne«s 2. opl. fra juni 1826 var Weyses mel. tilføjet.

${ }^{37}$ ) Den første i brev til P. Fenger 14.3.1843, den anden i »Rosen-kjæden « s. 365 .

${ }^{38}$ ) Den stod hos Thomissøn 1569, Kingo 1699 og Breitendich 1764, men optryktes derefter først hos Laub 1887.

${ }^{30}$ ) Den staar selv nr. 634 og forsøgene nr. 649 til 652: „Himlens morgenrøde《, 》Jesus, himmelfaren« og »Kraften fra det høje«.

$\left.{ }^{40}\right)$ »Danske Kæmpeviser til skole-brug « 1847.

41) Førsteudgaven af Sangværk II, 1839/41 er ligesom Sangværk I uden melodiangivelser. Jf. dog note $30 \mathrm{~b}$.

42) De ovennævnte til »Rosen-kjæden«s nr. 17: »Gud planted en have«, nr. 26: »Gud naade mig stakkels gamle mand« (teksten har dog »Aksel 
»Lovet være du, Jesus Krist«, er gaaet ind blandt vore faste salmemelodier siden Rungs koralbogstillæg 1857. Af 2-liniede med mellemog omkvæd har en af melodierne til »Et barn er født i Bethlehem« beskæftiget Grundtvig, enten den ældre hos Zinck (1801, nr. 15) eller den folkelige vandremelodi, vi nu har brugt siden Berggreen (1853, nr. 25 a); endvidere »Harpens kraft«, hvis mellem- og omkvæd: »Strengen er af guld« og »Saa lifligt legte han for sin jomfru« Grundtvig lempede til »Guds menighed, syng for vor Skaber i løn« (1850), og hvis smukke melodi (hos Rung 1857 og Barnekow 1878) Laub har genoptaget (1918). Af de sjældnere folkeviseformer er Grundtvig endelig blevet fængslet af to. Af den lille strofe »Jeg gik mig ud en sommerdag at høre« (den eneste, vi har overleveret) inspireredes han til 6 sange, 4 folkelige og 2 aandelige, alle med samme begyndelse $\left.{ }^{43}\right) . \mathrm{Og}$ af det sjældne versemaal, vi kender fra Ewalds »Liden Gunver« (den saakaldte »Stalt Elin«-strofe) byggede han - foruden pragtstrofen »Om Dannemarks kvide« - bibelviserne »Der sad en svend i blaamænds land / saa tankefuld (»Kammersvenden fra Morland《 SV. II, 97) og »I dommertiden i Bethlehem / var hungersnød« (»Ruth« SV. II, 45).

Om Grundtvig endelig, da han skrev »Det er saa yndigt《 i 1855 , har haft Rahbeks »Og nu en skaal for det elskte køn « $i$ tankerne ${ }^{44}$ ) med en af de gamle klubvisemelodier til »At slyngler hæves«, faar staa hen. Weyses melodi var dog kommet allerede 1833 til P. Fengers svigerfader, justitsraad, prof. Ludv. Mantheys sølvbryllup.

Over for vore traditionelle salmemelodier stod Grundtvig da personlig konservativt og over for anvendelsen af verdslige melodier moderat. Var hans syn end »dunkelt«, saa havde han dog ligesom den indviedes takt. Hvor hans tilhængere imidlertid gik uden om ham eller videre end han, formaaede han hverken at bremse eller vejlede dem. Hans dybe indsigt i salmernes vasen og funktion rakte ikke til deres melodier, og hans klarhed over kirkens historiske situation indbefattede ikke dens forhold til musiken.

Reformationstidens koraler var gennemgaaende i kirketonearter

Thordsøn«-visens omkvæd), nr. 12 (m. fl.): »For al den del, som Gud har gjort《 og nr. 35 (m. fl.) : »Moses var gammel, af verdens uro«.

43) 1840: Om Fønikssagnet og kongeskiftet, 1847: Om modersmaalet og folkevisen, 1850: Om Istedslaget og 1870: Om hjærtefuglen. De to aandelige sange, begge fra 1846 , lod han ikke selv trykke. De behandler som pendanter Gudsoplevelsen som mystik (»Fuglesangen«) og som menighedsbevidsthed (»Himlens nattergale«). Jf. Carl Koch: »Grundtvigske toner« $1925^{3}$, s. $83-103$.

${ }^{44}$ ) Som antydet af H. Brix i $\gg$ Dansk lyrik gennem tre aarhundreder $\ll 1928$. s. 175 . 
og $\mathrm{i}$ en mere eller mindre levende rytme. Ortodoksien forsøgte at nærme dem til den da opkomne, dramatiske udtryksmusik i dur og moll, og op mod rationalismens tid udjævnedes deres rytme til fuldstændig ensartethed, kun afbrudt af hvilepauser (fermater) ved alle linieudgange. Den tonale ændring kan forstaas som en del af den almindelige overgang fra et objektivere til et subjektivere udtryk. Den rytmiske ændring kan maaske være paavirket af det 17.-18. aarhundredes smag for regelmæssige vers (strengt jambiske, strengt trokæiske o.s. v.), men er i det hele vanskeligere at forklare. Da den kun omfatter salmen, kan man gætte paa, at rationalismen her forsøgte at stimulere den vaklende tro med »højtidelighed«. Forsøget faldt trist ud. Zincks og Weyses koralbøger (fra henholdsvis 1801 og 1839) kan ikke engang sammenlignes med en kirkegaard (der er dog blomster og forskelligheder), de er som et statsfængsel af halvnoder. Føjer man hertil Berggreens tempotal ${ }^{45}$ ), der viser, at man fremførte disse koraler henved dobbelt saa langsomt, som vi synger dem nu, og endelig vidnesbyrdene om de flere timer lange prædikener, bliver billedet sørgelig klart: Der var, da Grundtvig traadte frem, visselig intet forlysteligt ved »religionen«. Kirkesangen hos almuen havde Schulz karakteriseret som »ein rohes Geschrei $\ll^{48}$ ); i købstæderne forstummede den. Romantikens tyske salme- og koralforskning fik kun en spag repræsentant herhjemme i Rudolf Bay; det blev helt andre veje, man betraadte, indtil Laub tog dens synspunkter op $^{47}$ ).

Om den første vej, 40-ernes overraskende og enestaaende reaktion mod »den døde koral«, fortæller Carl Thrane ${ }^{48}$ ):

》Man vilde synge, man vilde danse, man var (fra det verdslige musikliv) vant til iørefaldende, velklingende melodier. I kirken kunde man ingen vegne komme under den langsomme bevægelse og de evige fermater ... Saa foretrak man at tie fremfor at synge. Kun ikke i Grundtvigs menighed i Vartov kirke.«

45) Berggreens koralbog 1853. Om tempotallene se indledningen til 1. udg. (»Om menighedssangen «) s. XVII f. I forordet til 3. udg. 1863 kalder B. dem vel langsomme, men beholder dem, da man nu visse steder synger for hurtigt. I 4. udg. 1868 meddeler han sine egne, lidt hurtigere tempotal, da han nu er kommet under vejr med, at andre »af gammel vane eller af dorskhed foredrage melodierne alt for langsomt «. - 11 af disse tempotal vil findes omregnet $i$ mine "Studier $i$ poetisk og musikalsk rytmik « 1938 , s. 176 , note 3 . For to salmers vedkommende vil her tilnærmelsesvise (!) sammenligninger kunne drages.

${ }^{48)}$ I det s. 14 anf. skr. 1790.

47) Rud. Bay: »Om kirkesangen i Danmark og midlerne til dens forbedring « 1840, P. Hamburger: 》Thomas Laub« 1942, s. 22-30, og E. Bangert: 》Gudstjenestemusik « 1944, s. 53 ff.

48) 》Cæciliaforeningen og dens stifter« 1901, s. $121 \mathrm{ff}$. 
Her blev der til festsalmerne »ofte sunget populære, verdslige melodier, og da Grundtvig var tilfreds med dem og de i høj grad tiltalte menigheden, gik man videre ad denne vej. I valget af melodierne var man ikke kræsen, først og fremmest kom det an paa, at de vare godt kjendte og yndede. Hvorledes det egentlig var gaaet til med disse melodiers opkomst i menigheden, stod som en gaade, de skjød ligesom vilde planter op af den jordbund, hvori de trivedes. Medens det store problem, hvorledes der skulde skabes en tilfredsstillende kirkesang, endnu var uløst . . . havde Vartov-menigheden hugget knuden over og, hvad den saa sang, sang den af det fulde bryst. Man talte om denne sang i byen som om noget ganske nyt eller som et kuriosum, og mange gik i Vartov kirke for at høre med egne ører. Grundtvigs prædiken kunde ikke trætte ukaldede aander, da den var meget kort, og ved den af menigheden baarne sang, det dæmpede orgel og det fine klokkespil gav den lille kirke et totalindtryk af hygge og andagtsfuld glæde.«

Hvad man sagde ude $i$ byen, kan vi ane af Erik Bøghs føljetoner: 》Jonas Tværmoses ærgrelser $\left.{ }^{48}\right)$. Her skildrer en pebersvend lydene fra nabolejlighederne juleaften:

»Familien, der bode ved siden af mig, hørte til »den lystige menighed« og sang kæmpeviser, Brorsonske psalmer og Vartovs-gallopader mellem hinanden. Ogsaa taler blev der holdt og det meget højrøstede. Især var der en taler, hvis stemme trængte gennem mure og vægge, og som jævnlig producerede sig. Blandt andre foredrag holdt han et, hvoraf jeg ikke kunde undgaa at høre flere sætninger. Det var i den humoristisk-opbyggelige genre og gik ud paa, at det var en fødselsdag »eller, som vore hjemme-tyskere kalder det paa deres kauder-vælsk: en geburtsdag«, vi fejrede juleaften, og at geburtsdags-barnet var al ære værd - o.s. v. Et øjeblik efter hørte jeg hele koret med den inderligste begejstring istemme: »Og skam faa den, som ikke ...«- Jeg er hverken bigot eller intolerant, men jeg tilstaar, at denne julehymne, hvor velment den end kunde være, var mig uudholdelig.«

Hvad det var, de første grundtvigianere sang, ved vi nøjagtigst for de fortællende visers vedkommende. Paa dette punkt stemmer J. C. Lindbergs »Rosen-kjæden« (1843) sammen med P. O. Boisens »Bibelske og kirkehistoriske psalmer og sange for skolen« $\left.(1853)^{50}\right)$.

49) I hans blad »Folkets avis« fra juleaften 1861. Første del som særskrift 1863, saml. udg. $1877^{-3}$ og $1894^{4}$. Her efter sidste udg.: 》Juleaftensbetragtninger« s. 16. Jeg takker dr. Nils Schiørring for denne henvisning. - Om Gebauers og Gades respektløse afvisning af visse Rung'ske og Berggreen'ske melodier jf. P. Hamburger: 》Th. Laub« 1942, s. 32.

${ }^{50}$ ) Lindberg forklarer sine fakultative melodiangivelser i sin fortale s. IX ff. (selve melodiregistret s. 361-369) og forsvarer sit valg af verdslige toner med, »at det samme har været brugt til andre tider, og falder naturligt, hvor der kommer noget liv i psalme-sangen « - uden klarhed over forskellen paa gammel og ny melodik (jf. s. 35). - Boisen angiver de melodier, han har brugt ved sin undervisning, og indleder sit forord med at begrunde dette: „Gode psalmer og sange af historisk indhold, sungne paa livlige og velklingende toner, er tilvisse et godt middel til at frem- 
Det er her først og fremmest folkevisernes parade, vi møder, og det er til Grundtvigs fortællestil slet ikke værst. Foruden de allerede nævnte $\left.{ }^{51}\right)$ findes »Marsk Stigs døttre« $(3,13,15,36,37,41,96,99$, 108), 》Svend Felding《 $(14,22)$, »Axel og Valborg« $(16,73,77)$, »Liden havfru《 $(25,35)$, 》Berner Rise《 (54), »Hr. Tønne《 (66), »Hr. Esbern《 (69), 》Ungen Svegder《 (75), og de yngre: »I Juras skjønne dale《 $(19,59,72)$, 》Asker Ryg« $(39,58)$, »Der boede en konge« (48), 》Det var en lørdag aften« (98), og »Hvad vindes paa verdens vidtløftige hav $\left.\ll(104)^{52}\right)$. Mere problematisk er benyttelsen af den nye kunstsang. Boisen anfører »Hvor bølgen larmer« (af Bay, $10,52,55)$, 》I alle de riger og lande《 (sikkert af Gebauer, 20), »Paa Sjølunds fagre sletter《 $(24,28)$, »Hr. Peder kasted runer《 (31), 》Sol er oppe« (vel af Th. Fenger, 67, 85. Til »Aanden opgav enkesønnen«), 》Villemoes« (40,40 b, 45, 97, 101. Til tekster med optakt) og »Modersmaalet« (107. Til tekst uden optakt). Og Lindberg gaar herudover helt til smældende hæderssange og klubviser, f. eks. »Duftende enge« (262, til »Lovsynger Herren, min mund og mit indre«), »Hold lampen tændt, sy tøfler og sko« $(157, \mathrm{~m}$. fl., af »Dragedukken«), 》Skaberen skued den nyskabte klode« (183, til »Hvo vil med til himmerige«), 》Dannevang med grønne bred《 (168), 》Vort fødeland var altid rigt《 $(189,203)$ o. m. fl..$\left.^{53}\right)$. Her sættes de endda til

bringe liv i skolen.« - Begge fremlægger deres melodier og melodiforslag som prøver og ser dem gerne afløst af bedre. - Lindbergs tidligere samlinger, 》Nogle danske og tydske psalmer《 1831 og 》Zions harpe《 1831 angav kun almindeligt kendte salmetoner.

51) S. 24. - 》Jeg ved et evigt himmerig《er under betegnelsen $\gg$ Der stander et slot i Østerrig « benyttet til nr. 0, 2, 23, 27, 50, 86, 100, 102, 109 og 111 hos Boisen. Hans numre anføres ogsaa ovenfor i det følgende. - Af ikke Grundtvig'ske viser har de tre om 》Jefta《 (30), 》Job《 (43) og 》Kvinden af Samaria land« (62) m. mel. særlig interesse, samt angivelsen, at »Goliath « (33) skulde have egen tone.

52) Hertil hos Lindberg: »Der var en konning i Lejre« (56 m. fl.), »Den fromme fru Signe paa sotteseng laa《 $(67,274)$, 》Om Dannemarks kvide《 (182) og 》So lebe wohl, du stilles Haus« $(7 \mathrm{~m}$. fl.). Ogsaa Lindberg foretrækker 》Jeg ved et evigt himmerig《 $(12,23,62,83,127,142,176,220,232$ og 272).

$\left.{ }^{53}\right) \gg$ Af kærlighed, min ven« $(187 \mathrm{~m}$. fl.). »Barnlige dage saa blide« (231). »De klare bølger rulled《 (13 samt endnu fire, alle i metret »Fryd dig, du Kristi brud«). »Du, hvis aasyn glæden tænder《 (278). »Du lille ø《 (201). »Du ærlig hvile skal i graven« (201). »En grube staar i bjergets indre« (149 m. fl.). »Fugl Phønix« (17). »Her ved havets aabne bredder« (37, 146, til »Mellem brødre«). »Hvad har stakkels neger gjort« (161 m. fl.). 》I dalens skød en hytte laa《 (163). 》Ja, højt under taget, hvor svalen den bor « (28). »Kong Fredrik den Sjette henslumred i fred « (241). »Naar i bondens tavse bo« (206). »Naar vintersneen fyger« (237). 
rigtige salmetekster, saa misforholdet mellem ord og toner træder grellere frem. Endelig har begge samlinger nogle nye melodier af amatører, knyttet til bevægelsen ${ }^{54}$ ), og Boisens nogle Weyse-sange ${ }^{55}$ ) samt nykompositioner af J. C. Gebauer (26, samt s. 152) og Henrik Rung (21, 32, 84: »Tag det sorte kors fra graven« og 112: »Kirkeklokke«).

Vel havde folket saaledes taget sagen i sin egen haand; men det kom ikke til at dø i synden. Samme aar som Boisens samling kom, rettede Berggreen $\mathrm{i}$ indledningen til sin koralbog (»Om menighedssangen « 1853) et vægtigt angreb mod melodibyttetrafiken ${ }^{56}$ ). Uden direkte at nævne Vartovsangen, opregnede han dens repertoire med bestemt afvisning (s. XIV) og søgte at gøre klart, at hver melodi har sit eget stemningspræg, som man ikke kan ændre blot ved at give den en anden tekst: „Tror man uden anstød at kunne bruge samme melodi den ene dag i lystigt lag, næste dag i kirken!« (s. XV). Hensigten med Berggreens eget koralbogsarbejde var det $\mathrm{i}$ og for sig rigtige kompromis: »Opnaaelsen af en liveligere kirkesang uden

»O bor du histoppe, du ørnebrud« (101). »Rolfs skattekonge fejg og ræd« (182). »Sørge, hvo som sørge vil« (224). »Underlige aftenlufte《 $(75 \mathrm{~m}$. fl.). »Velkommen, livsalige aften « $(30,32)$. - Endelig bringer P. Rørdams »Psalmer《 1856 (den saakaldte »Lyngby-salmebog«, nummereret som 》Tillæg《 fra 618-864) spredte melodiangivelser som de første hefter »Festsalmer«. Af verdslige findes »Der stander et slot i Østerrig« eller 》Jeg veed et evigt himmerig« (til 640: 》Maria sad« og 663: 》En sædemand« (?) m. fl.), 》O sanctissima« (til 718: »Kirken er som himmerige« og 823: 》Skabt er baade jord og himmel«) og »Far, verden, farvel« (til 854: 》O kristelighed«). Nogle melodiangivelser er tankeløst overført fra samlinger med anden orden (Festsalmer), saa der staar »Samme melodi«, hvor forrige salme er i andet versemaal (saaledes f. eks. nr. 643, 645, 646, $672,679,777-784,787-795$, d. v. s. alle evangeliesalmerne til »Kirken den er et gammelt hus $)$.

$\left.{ }^{54}\right)$ Lindberg nævner (s. X) J. Josephsen, H. Jørgensen og A. C. E. Lindberg. Hos Boisen figurerer en anonym (34), H. M. Hansen $(6,29,44,46,82$, $103,105)$, Th. Fenger $(17,71)$ og T. Busck $(87)$.

${ }^{55)} \gg$ Den signede dag«, »Dejlig er den himmel blaa« og nogle morgen- og aftensange.

${ }^{58}$ ) Hans historiske fremstilling (s. XIV i 5. udg. 1875, hvortil her overalt henvises) lider under hans manglende sans for kirketonearternes betydning. Men hans henvisning til C. A. Thielo (fra hvem man egentlig mindst skulde vente støtte) er berettiget. Thielo skriver i »Tanker og regler om musiken « 1746, s. 9: »Man tager uden betænkning, som jeg selv har hørt og erfaret, forliebte Italiænske arier, sætter $i$ et andet sprog en aandelig tekst derunder, og fører dem saa op paa hellige steder; men de klinger, paa reen dansk at sige, alt for forliebt, og følgelig ere in Stylo Ecclesiastico foragt værd.« Jf. videre Berggreens forsøg til en gruppering af salmemelodierne efter stemningspræg i forordet til 2. udg. 1859, s. VIf. 
at opgive den kirkelige charakter « (s. XIII). At hverken han eller nogen af hans romantiske fagfæller - efter vore begreber - alligevel naaede dette maal, skyldtes, at man i opfattelsen af det kirkemusikalske stod over for en afbrudt eller udslukt tradition og saaledes savnede ethvert objektivt holdepunkt $t^{57}$ ). Den godt 30-aarige strid, som begyndte med hans koralbog og endte med Laubs fremtræden (1887) - og dermed med indvarslingen af en ny strid bragte ingen egentlig klaring, intet sejrende, vejledende og befrugtende synspunkt. Man stredes i alle koralbøgernes fortaler; alle stod mod alle. Berggreen intimiderede Vartovkredsen; denne søgte støtte hos Rung, som ydede den - omend med betænkelighed - dels gennem sine $30 \gg$ Melodier til Fest-psalmer $\left.\kappa^{58}\right)$, dels ved at beskylde Berggreen for at tilsidesætte Weyse. Berggreen skammede til gengald Rung ud for hans verdslige salmemelodier ${ }^{50}$ ) o. s. v. Et egentligt referat hører hjemme $i$ anden sammenhæng ${ }^{60}$ ); her nøjes vi med at konstatere det eneste fælles hos tidens salmekomponister: Stræben mod en fornyet livlighed og udfoldelse af hver enkelt salmes særlige stemningspræg. Da dette saa godt som udelukkende forsøgtes med kunstsangens midler, var den stadig lurende fare den romanceagtige overdifferentiering. For de Grundtvig'ske syner af det store fællesskab kneb det at finde bærekraftige toner.

5. ROMANTIKENS GRUNDTVIG-KOMPOSITIONER. Originalkompositionerne til Grundtvigs aandelige digtning begyndte paa højeste plan med, at Weyse (1774-1842) opstillede dens to prototyper. Med »Den signede dag« (1826) skabte han den nye, kirkelige melodi, paa en gang levende og storslaaet, og dog hjemlig og hjertevarm, paa højde med Grundtvigs syn af »Jordens bold«, som gløder i det himmelske lys. Den staar urørlig som kulminatio-

$\left.{ }^{57}\right)$ Berggreens egen famlen ses af hans $i$ og for sig fine, men rent negative bemærkninger s. XVI: »Den religiøse glæde, der bør aande $i$ en hymne - og den patriotiske begejstring $i$ en fædrelandssang; den milde, andagtsfulde ro $i$ en takkepsalme - og følelsen af velbehag i en selskabssang; det bønlige udtryk i psalmen - og det erotiske sværmeri i en elskovsvise; det med trøst og haab blandede veemod i en gravpsalme - og det lidenskabelige udbrud af den enkeltes smerte i elegien / ere tonefarver, der for den mindre skærpede sands lettelig glide over i hinanden; og dog er forskjellen stor. Musikeren raader her over mange udtryksformer, som rigtigt anvendte, ikke ville forfejle deres virkning . «- Enhver positiv bestemmelse mangler.

$\left.{ }^{58}\right)$ 》Tillæg til Weyses koralbog« 1857.

${ }^{59}$ ) Se den bitre note 2 (s. XVI i B.s koralbog) fra 1868.

$\left.{ }^{60}\right)$ Se C. Skous noget panegyriske $\gg$ A. P. Berggreen « 1895, s. 125-173, samt de anf. skr. af C. Thrane, s. 123-132, og P. Hamburger, s. 28-33. 
nen mellem Zinck og de senere romantikere. Og med »Velkommen igen, Guds engle smaa« (1838) førte han den aandelige visetone fra Schulz og hans egne morgen- og aftensange over til Grundtvigs dybere tekst - til et andet højdepunkt med genrens ædleste træk: inderlighed og renhed.

Den næste generation viser en kurve - vi vilde kalde den dalende - fra kirkesalme til stemningsmelodi. Helt paa højde med »Den signede dag《 i almen og samlende udtrykskraft er kun $L$. $M$. Lindemans (1812-87) 》Kirken den er et gammelt hus« (1840). Derfra svinger han over den fine »Hyggelig, rolig« (1840) til den brede og varme, men lidt almindelige »O, kristelighed« $\left.(1862)^{81}\right)$. Tilsvarende spænder $A$. P. Berggreen (1801-80) fra den holdningsfulde »Velkommen igen, Guds engle smaa« (1832, tr. 1834) og den fine »Vær velkommen, Herrens aar« (1852) til de lidt svagere, stemningsmalende »Julen har englelyd《 (1852) og »Guds menighed, syng « (1852) - og H. Rung (1807-71) fra de fastere, saa enkelt og klart harmoniserede »Tag det sorte kors fra graven« (1853), »Alt staar i Guds faderhaand« (1857) og »Paa Jerusalem det ny« (1859) over den vel svungne $\gg I$ al sin glans « (1859) til de rene stemningsstykker »Kimer, I klokker« (1857) og »Kirkeklokke《 $(1853)^{62}$ ). Hvad det især kneb med, ser man klarest af de to Weyse-elevers melodiforsøg til »Krist stod op af døde« (Berggreens 1852, Rungs 1853). Grundtvig var her naaet frem til en samling om opstandelsesunderet og dets simple, trefoldige lovprisning, af samme overpersonlige, mærkeligt medrivende og strømmende kraft som den gamle sekvensmelodi (jf. s. $21 \mathrm{f}$.). Hertil ved de to romantikere kun at sætte en venlig og ærbar treklangsmelodik $i$ en passiv og afspændt rytme. Det blev en beskeden, bedsteborgerlig monumentalitet, ikke det ufattelige raab af lykke.

Større kraft kunde man have ventet hos J. P. E. Hartmann (18051900), men han brugte kun sin stærke, »nordiske« tone i den verdslige musik ${ }^{63}$ ). Selv egentlige kirkesalmer som »Blomstre som en rosen-

B1) Forvirrede i udtrykket og nær det usyngelige p. gr. af den besynderlige, springende melodik forekommer derimod andre i Lindemans store uegale produktion, f. eks. »I Nazareth der var saa smukt« (1874) og »Talsmand, som paa jorderige $\ll$ (1876).

$\left.{ }^{62}\right)$ Nær de første staar den rene og blide $\gg \mathrm{O}$ lad din aand nu med os være《 (1857). Langt almindeligere er »Sin vogn gør han af skyer blaa《 (1857) og den melodi, der tillægges Rung, til »Som dug paa slagne enge《 (1868).

${ }^{83}$ ) Kai Aage Bruun mener dog at høre den i hans melodi til 》Giv mig, Gud, en salmetunge« (1860) (»Grundtvig og musiken« i Nationaltidende's kronik 27.5.1942). - Interessantere forekommer mig den om Brahms mindende »Dybt fornedres skal enhver« (1871), der begynder saa ejendommeligt og stærkt, men svækkes i sidste halvdel. 
gaard《 (1861), »Mindes vi en fuldtro ven« (1860) og »Fred til bod for bittert savn« (1866) komponerer han viseagtigt sødmefyldt, de sidste endda i farligt valsenære takter $\left.(6 / 4 \text { og } 6 / 8)^{64}\right)$. Til gengæld gav han nogle af Grundtvigs virkelige viser, »Mellem brødre kaldt den lille« og »Blomst kan visne«, 》Der sad en fisker《 og »Der sad en svend i blaamænds land« (alle 1860) saa rent og inderligt udtryk, at »den anden linie« fra Weyse fandt fortsættelse her. I dem, og ogsaa $\mathrm{i} »$ Blomstre som en rosengaard«, mødes Grundtvig med en jævnbyrdig. Fra dem skal vi bevare romantikens bedste indsats (omend i det smaa, hvor teksterne alene gjorde det muligt): det mærkelige præg af samtid og samhørighed, som ingen eftertid kan genskabe $^{85}$ ).

Den tredie generation fuldførte romantikernes arbejde paa at give hver Grundtvig-sang, som var i brug, dens egen melodi med dens eget stemningspræg. Hovedmanden, Chr. Barnekow (18371913), arbejdede paa begge linier og med samme kurve som forgængerne. Fra fast formede, omend vel følelsesfulde menighedssange som »Du, som gaar ud fra den levende Gud« (1858), »Kærligheds og sandheds aand《 (1868) og især »For dig, o Herre, som dage kun« (1870) forvildede han sig ud i romancens faldgruber. »Vidunderligst af alt paa jord« (1870) er med sin ømme slutning ovre i føleriet; og i »Kom, Gud Helligaand, kom brat《 (1859) falder han for fristelsen til punktkarakteristik. For rigtig at illustrere det ene ord i første strofe: »gennembryd«, giver han det en spændt ledetone, som saa maa slæbes med til de øvrige tekststrofer, hvor den virker umotiveret og kunstlet. Ogsaa hans aandelige viser spænder fra den stilfærdigt fine, folketoneprægede »Jeg havde min vugge ved Nilens bred« (1868) og den hjertelige »Morgenstund har guld i mund« (1856) til den lidt eksalterede »Jeg gik i marken« (1868) og den ret ordinære »Der er en vej《 (1878).

$\left.{ }^{64}\right)$ Jf. hertil den fastere »Kommer, sjæle dyrekøbte« (1860) og omkvædsvisen 》Vorherre han er en konge stor « (1861).

$\left.{ }^{65}\right)$ Af samme slægtled bør nævnes C. Balle (1806-55): »Det kimer nu til julefest《 (1850), »Et lidet barn saa lysteligt« (1863) og »Herren han har besøgt sit folk « (1863), - H. Matthison-Hansen (1807-90): 》I Wittenberg i Sachsenland《 (1843), 》Verdens igenfødelse《 (1852) og 》Denne er dagen« (1876), - J. C. Gebauer (1808-84): »Lille Guds barn, hvad skader dig« (1873), - A. Gether (1809-73): »Hyggelig, rolig« (1860) og »O du Guds lam« (1860), - Cora Nyegaard (1812-91): »Rejs op dit hoved, o kristenhed « (1840) - og N. W. Gade (1817-90): »Hør vor helligaftensbøn« (1852). Hertil kan føjes den anonyme komponist af den kendte melodi til »Dejlig er den himmel blaa《, om hvilken Berggreen (i sin koralbog 1853, nr. 29 b) kun oplyser: »Comp. omtrent 1840 af en gammel mand, der ellers aldrig har givet sig af med composition.« 
Den næstvigtigste skikkelse var $H$. Nutzhorn (1833-1925), der i sit fortjenstfulde arbejde med at tilrettelægge hele det Grundtvig'ske sangstof for højskolen ogsaa selv greb til nodepennen. Det blev vel ikke den store inspiration, men bl. a. dog en salme som »Øjne, I var lykkelige« (1866) og viser som 》Ved Babylons floder《 (1855) og »Kong Farao var en ugudelig krop« (1864), paa sin vis naive, men nok saa djærve og friske som Barnekows ${ }^{68}$ ).

Omend meget af det romantiske stof nu med rette er fortrængt, kan man aldrig frakende det dets historiske betydning. Det ledte den nyvakte, vildt strejfende sanglyst ad de første ordnede baner. At det skulde forældes, var næsten uundgaaeligt; den sarte musik er sædvanlig bagefter de andre kunstarter i udviklingen. Hvem kunde da forlange, at vi skulde have en musikalsk fornyer just samtidig med Grundtvig? Men det blev bevægelsens og endnu min egen generations barndomsminder, som vi nu - efter en mellemliggende kamptid - atter kan omgaas med nænsomhed.

86) Af samme slægtled kan nævnes A.H. Winding (1835-99): »Som hønen klukker mindelig《 (1864), - J. Glæser (1835-91): »Har haand du lagt paa Herrens plov« (1880), - Emil Hartmann (1836-98): 》Som foraarssolen morgenrød《 (1868), - C. C. Hoffmann (1839-93): »Hil dig, Frelser og Forsoner« (1878), - Viggo Kalhauge (1840-1905): »Apostlene sad i Jerusalem« (opr. til »Billed sig gjorde Gud af støv« 1876), - Lars Nielsen (1843-95): „Udrundne er de gamle dage《 (opr. til »Saa vidt som solens straaler stige « 1868) og 》Denne er dagen « (tr. 1901) - og J. H. Nebelong (1847-1931) : »Nu falmer skoven trindt om land« (i hans »Aandelige sange 2 . udg. u. aa.).

Som de vigtigste samlinger, der bragte romantikens melodier til Grundtvigs salmer, skal anføres: A. P. Berggreens skolesangbøger fra $1834 \mathrm{ff}$. og hans koralbog $1853,1859^{2}, 1863^{3}, 1868^{4}, 1875^{5}$ (m. tillæg 1856 og 73; nyudg. v. J. H. Nebelong 1898). - H. Matthison-Hansen: 》Asyl-sange《 1843. - Melodibilag til P. O. Boisens »Bibelske og kirkehist. psalmer og sange«, 2. udg. 1855 , særskilt som »Melodier« til samme v. H. Nutzhorn 1864. - H. Rung: »Fem psalmer af Grundtvig« 1857 og »Tillæg til Weyses choralbog « (paa særligt titelblad: »Melodier til: 'Fest-psalmer'«) 1857, $1868^{2}$ (4. udg. o. 1900). - L. M. Lindeman: 》Grundtvigs salmer med melodier« 1862. - Joh. Chr. Kalhauge: »20 melodier til Fest-psalmer af N. F. S. Grundtvig《 1863. - Viggo Kalhauge: »Fuldstændig samling af melodier til Grundtvigs Kirke-salmebog (Fest-salmer) « 1876 og senere (3. tillæg 1893). - J. P. E. Hartmann: »Davids sejerssang « (enkelttryk 1860), »Bibelske og kirkehistoriske smaasange《 1862, 》Aandelige sange« 1871, »Religiøse sange《 (sml. o. udg. v. Chr. Barnekow) 1897 og »Romancer og sange《 1. afd. (u. aa.). - »Melodier til N. F. S. Grundtvigs 'Sangværk til den danske kirke-skole'« 1870. - Chr. Barnekow: 》Tolv bibelske og kirkehistoriske sange af N. F. S. Grundtvig « 1868, »Aandelige sange $1863,1870,1903$, »Melodier til Tillæg til Psalmebog for kirke- og husandagt《 1878 og »Melodier til Nyt tillæg til (samme) « 1892 og senere. - M. T. Bredsdorff og H. Nutzhorn: "Melodier til Til- 
6. KIRKESANGSREFORMEN OG HØJSKOLEN. Da Thomas Laub (1852-1927) i 1887 udgav sit første skelsættende skrift »Om kirkesangen « og snart efter sine 》Kirkemelodier《 (1888-90, 1902), afløstes den lille salmestrid af den store, men ogsaa langt frugtbarere, som har varet til vore dage. Trods al produktivitet var romantiken kørt fast $\mathrm{i}$ tvivl og usikkerhed; reaktionen $\mathrm{m}$ a a t $\mathrm{e}$ komme. »Dette er værd at erindre«, skriver Hamburger ${ }^{67}$ ); 》det var ingen paradisisk uskyldighedstilstand, Laub kom og forstyrrede. Han traadte med det samme haardt paa samvittigheden.« Ogsaa denne strids data og faser hører hjemme $i$ anden sammenhæng ${ }^{88}$ ); her skal vi kun betragte dens forbindelse med Grundtvig-teksterne.

Romantikens første frugt var dens kunst; dens anden, senere modne, var dens historiske kunstforskning, herunder den poetiske og musikalske hymnologi. Dens repræsentanter herhjemme var de to lærde kunstnere: Grundtvig og Laub. Som Grundtvig havde nedbrudt rationalismens produkter, nedbrød Laub romantikens ${ }^{69}$ ) - ikke af negativitet, men fordi han med sine forudsætninger i tysk forskning ${ }^{70}$ ) var naaet til det positive begreb, romantikerne havde savnet.

lægget til (samme)«, Nyborg 1874, og »Salmemelodier, 2. samling, . . melodier til det nye Tillag til (samme) «, Nyborg 1892 (den første med et ganske interessant forord; den anden kommenteret). - »Melodier til 'Sangbog for den danske folkehøjskole'« samlede af Anders Kirkegaard og Niels Vad, udg. af Jens Bek og N. Johan Laursen, Aarhus 1890. »Melodierne til 'Sangbog udgivet af foreningen for højskoler og landbrugsskoler'« samlede og udgivne af H. Nutzhorn, Nyborg 1904 (ved siden af Berggreens arbejder den vigtigste samling med sanghistorisk indledning og kommentar). - Af de senere koralbøger før Laub skal sluttelig blot nævnes »Menighedens melodier« udg. af L. Birkedal-Barfod, O. Madsen og S. Widding, I-II, 1914, p. gr. a. denne samlings omfang og dens særlige ordning efter strofeformer.

07) 》Th. Laub« 1942, s. 33.

88) Jf. foruden Laubs egne skrifter, især hovedværket 》Musik og kirke« 1920, $1940^{2}$, P. Hamburger: »Th. Laub« 1942, s. 22-58, 79-121, J. P. Larsens 》Omkring Povl Hamburgers Laub-biografi《 og »Laubs melodiredaktioner og ord-toneproblemet« (Samf. Da. kirkesangs aarsskr. 1943, s. 75 ff. og $1945-46$, s. $28 \mathrm{ff}$.) samt hans artikel 》Th. Laub og den danske sang《 (Tidsskr. Danmark, 1944, s. 415-420); E. Bangert: »Gudstjenestemusik« 1944, s. 55-59; og A. Arnholtz: »Vor folkesangs 'Fire store'« (om Th. Laub, Carl Nielsen, Thorv. Aagaard og Oluf Ring, 》Landet《 13.6.1946).

89) Som Grundtvig tog slægtleddet af digtere forud for ham selv haardt $\mathrm{i}$ skole i slutningen af 》Verdens krønike《 1812, behandler Laub sine forgængere kritisk i »Musik og kirke《 1920, s. 131-149.

$\left.{ }^{70}\right)$ Se referatet af de vigtigste herhenhørende værker hos P. Hamburger: »Th. Laub«, s. $25 \mathrm{ff}$., nemlig P. Mortimer: »Der Choralgesang zur Zeit der Reformation « 1821-23; A. F. J. Thibaut: »Über die Reinheit der Tonkunst《 1824; K. v. Winterfeld: »Der evangelische Kirchengesang« I-III, 
Uden det, der for Laub maatte staa som objektive holdepunkter, havde hans egen usvigelige sikkerhed og udholdenhed under den utrolige modstand, han mødte, ikke været mulig; uden det havde han ikke kunnet fuldføre sit helstøbte livsværk eller dannet skole. Som Grundtvig havde gjort den folkelige sangdigtning til en af sine hovedopgaver, gjorde Laub arbejdet med den folkelige melodi til sin livsgerning - ikke blot til en bibeskæftigelse, som de store romantikere havde nøjedes med - og naaede derved en musikalsk indsigt lige saa dyb som Grundtvigs poetiske.

Lad mig prøve at sammenfatte de Laub'ske bestemmelser: Den folkelige, og dermed den kirkelige, melodi er sædvanlig strofisk d.v. s. en gentagelsesdel. Derfor tjener den ikke ordet, som den skal, ved at illustrere detailler, men ved at danne en rummelig helhed, hvis aand og holdning svarer til tekstens helhed. Dens præg skal være alment, men ikke derfor almindeligt, intetsigende. Den skal bære teksterne frem i levende rytmer og klare melodiske skridt, som en forsamling kan synge baade smukt og fejlfrit. Derfor skal de forstenede koraler have deres oprindelige rytmiske liv tilbage; derfor skal melodien, baade i gammel og ny kirkesang, udfoldes selvstændigt af det vokale; den skal ikke blot være en øverste »afledet« kontur af nogle sammenhørende akkorder. Derfor melder de gamle kirketonearter sig som den egentlig sangbare melodik, og den objektive harmonisering foretrækkes som melodifremhævende fremfor kunstmusikens stemningsmalende. Hvor disse træk var fælles for kirke- og folkesang (op til og med reformationen), kunde gejstlige og verdslige sange endnu bytte melodier uden skade. Hvor den verdslige musik derimod (siden renæssancen) udviklede sit eget følelsessprog og enkeltmandsudtryk, blev den stadig mere fremmed for kirken. Kirkens sang er nemlig altid eet. Den kan skifte ydre skikkelse, fra gregoriansk over Palestrina-kunst til luthersk koral; men dens engang skabte værdier beholder gyldighed, og 》den kan aldrig optage noget fremmed . . som ikke er vokset ud af den ( $\left.^{71}\right)$.

Her var da omsider et syn som Grundtvigs, og her fulgte paa sin vis en gerning som hans. Den gamle melodiskat blev gjort brugbar igen, og en ny blev skabt. Om sit forhold til Grundtvig udtaler

1843-47; G. v. Tucher: »Melodien des evangelischen Kirchengesanges« I-II, 1848; og Johs. Zahn: »Die Melodien der deutschen evangelischen Kirchenlieder « I-V, 1889-93. - Hertil Rud. Bays lille skrift 》Om kirkesangen i Danmark og midlerne til dens forbedring « 1840 og Joh. D. Behrens' $\mathrm{Om}$ den Lutherske salmesang og dens gjenindførelse i den norske kirke« 1858.

71) Th. Laub: »Musik og kirke« 1920, s. 8 f. 
Laub selv ${ }^{72}$ ): »Hverken Joakim Skovgaard eller jeg - jeg tør nok tage ham med - bilder os ind, at vore arbejder er 'ægte grundtvigske', saa dumme er vi ikke. Men vi ved, at kun fordi vi har gaaet i lære hos Grundtvig, har vi kunnet gøre dem, som de er. Vi tør derfor sige, at de, i deres slags og paa deres omraade, er i fortsættelse af hans gerning. For mit vedkommende i dyb følelse af den store afstand.«

Hvor nær de to stod hinanden, ses bl. a. af den dybe indlevelse og sikre kunnen, med hvilken Laub lige fra begyndelsen løser de vanskeligste, liturgiske opgaver, som Grundtvig havde stillet. Til den skønne, alvorlige indledning til passionen »Hil dig, Frelser og Forsoner havde C. C. Hoffmann skrevet sin ganske afsporende, svulmende parademelodi. Laub (1891) genskaber bønstonen, inderligt bevæget og dog uden føleri, almen til fællesskabet. Det samme gælder hans endnu tidligere melodi til nadverliturgien »O du Guds lam《 (ca. 1888). Hvor føjer den sig ikke naturligt til de beslægtede messetoner som menighedens bøn; hvor bærer den ikke aarenes brug i sin enkle styrke - i modsætning til f. eks. Hartmanns helt krampagtige udtrykseruptioner (1871). Ogsaa hvor Hartmann er finest, er det lærerigt at sammenligne ham med Laub. »Blomstre som en rosengaard « bliver for Hartmann (1860) - med de indledende billeder fra det hellige land - en hjemlig romance af Ingemann'sk sødme; hvor sværmerisk nynner ikke slutlinien »Sarons yndigheder«! For Laub (1916) bliver den forjættelsen i dens vælde og jubel, kirkeaarets port. Her er fællesskabet med Grundtvig i aand og holdning, og her er bredde og kraft til menighedens fællesskab.

Genskabelsen af den objektive kirkesalme var Laubs vigtigste indsats. Under dette synspunkt restaurerede han de fleste gamle melodier til sit hovedværk »Dansk kirkesang« (1918). At hans originalkompositioner paa denne linie ${ }^{73}$ ) en enkelt gang kunde stivne i objektivitet - jeg tænker paa melodien til »O kristelighed« (1907), som skal kunne rumme baade denne tekst og »Far, verden, farvel $\kappa^{74}$ )

${ }^{72}$ ) I sit svar til pastor Ingerslev (Højskolebladet 1924, sp. 105).

${ }^{73}$ ) Jf. foruden de ovennæunte bl. a. »Herren han har besøgt sit folk « (ca. 1900), »Vorherre, til dig maa jeg ty《 (1915), »Alt staar i Guds faderhaand« (1916), »Alle mine kilder skal være hos dig« (1922) og den noget hæmmede »I kvald blev der banket paa helvedes port《 (1922). - Jf. som eks. paa hans kirkesalmetone til andre digtere »I lemmer, hvis hoved《 (o. 1890), 》Den store, hvide flok « (o. 1908) og 》Stat op, min sjal, i morgengry (før 1909).

${ }^{74}$ ) Ganske vist kun efter »Forslag til melodiansættelse《 i J. P. Larsens, F. Viderøs og M. Wöldikes »130 melodier《 1936. Laub selv nævner ikke 
- kan forklares forskelligt, blot ikke som udslag af tørhed eller kulde. Baade Laub og Grundtvig har maattet høre denne beskyldning $^{75}$ ), men har afvist den uforglemmeligt med deres aandelige sange. Her kan de to alvorlige lærde være glade som børn, f. eks. i »Alt hvad som fuglevinger fik« (1915), »Morgenstund har guld i mund« (1916) og »Dejlig er den himmel blaa« (1917). Her bliver forkynderne inderlige og stille, som i »Talsmand, som paa jorderige« (før 1909), »Kommer, sjæle dyrekøbte« (1915) og »Det er saa yndigt at følges ad « (1924). Og her bliver de hærdede stridsmænd milde og ensomme med deres skælvende bøn: „Sov sødt, barnlille« (1915) og »Aldrig, Herre, du forglemme« (1921) eller med det sidste, stort og tungt aandende farvel: »Gammel nok er jeg nu blevet« $\left.(1916)^{78}\right)$.

Det blev, som rimeligt var, det grundtvigske kirkefolk og den grundtvigske højskole, der trods indledende vanskeligheder dog først skønnede paa Laubs store gave og betalte prisen for at tage imod den: opgivelsen af barndommens kirkeromancer. Ved hans side stillede Carl Nielsen (1865-1931) sig, vel ikke saa hjemmevant i kirkehuset som Laub, men til gengæld den store, frodige komponist. Og til arbejdet paa »Folkehøjskolens melodibog« (1922) bad Thorvald Aagard (1877-1937) de to ældre og sin yngre kollega Oluf Ring (1884-1946) om bistand. Hermed var retningen knæsat og skolen dannet, gennem hvis virke og talrige elever den grundtvigske sang fornyedes. Laubs indsats staar dog øverst som den originale og afrundede. Carl Nielsens blev mere spredt ${ }^{77}$ ), og Aagaards og Rings mere bundet, efter at de to ældre mestre havde valgt tekster efter deres hjertes lyst $^{78}$ ). Det er vel et spørgsmaal, om f. eks. Grundtvigs

den Kingo'ske melodi til »Far, verden, farvel«, hvor han omtaler de andre (»Musik og kirke« 1920 , s. 124 f.).

${ }^{75}$ ) Laub utallige gange $i$ den stadig opblussende debat om hans melodier. Grundtvig vel tidligst af Martensen, der beklager savnet af inderlighed i hans salmer.

$\left.{ }^{76}\right)$ De sidste $\mathrm{i} \gg$ Tolv viser og sange《 1922, 》Aandelige sange《 1925 og 》Tillæg til Dansk kirkesang« 1930.

77) Fra hans hovedsamling: „Salmer og aandelige sange« 1919, skal nævnes »Guds engle i flok«; fra de »Tyve folkelige melodier« 1921 »Der sad en fisker《 og 》Udrundne er de gamle dage« (den sidste allerede $i$ »Viser og sange《 samlet af Erik Spur 1918). Tidligst, vist fra 1910, er »Paaskeblomst! en draabe stærk«. Iflg. fru Annemarie Carl Nielsen (se Th. Wellejus: »End er der sang i skoven « 1941, s. 151) blev salmemelodierne skrevet o. 1914-15.

${ }^{78}$ ) Af Aagaard bør nævnes de varme, brede salmer »Lovsynger Herren, min mund og mit indre« (i Højskolemelodibogen 1922) og 》Som solen oprinder morgenrød«. Den sidste (om Israels overgang over det røde hav) 
bibelviser i deres helhed er gaaet fri af forældelse, saaledes at de kan inspirere og bære en samlet nykomposition ${ }^{70}$ ). Disse detailproblemer vil vi imidlertid lade ligge og standse her.

Det har været maalet at vise den store, umusikalske, men sangkloge digters tre møder med musiken. Helt uden tragik er de ikke. Hvad kunde ikke være sket, om han havde haft en jæunbyrdig samtidig eller selv havde kunnet raade og hjælpe? $\mathrm{Nu}$ blev det først til Vartovsangens glade kaos, som vi dog ikke kan mindes uden fornøjelse. Saa til den famlende kirkelige romance, hvorfra dog fine sange og viser stadig aander den sære hjertevarme fra »tiden selv«. Og endelig til Laubs reformværk, som vi synes baade i kirkesalmen og visen omsider forener Grundtvig-teksterne med den musikalske storhed og dybde, de fortjener. Var det saa meningen med dem? vil den skeptiske spørge; er det ikke trods alt en eftertids toner? Grundtvig og Laub har gennem deres arbejde selv svaret, at kirkens sang altid er eet.

kom i »Fyrretyve melodier til bibelhistoriske sange« 1934. Heri bl. a. »Abraham sad i Mamrelund《, »Kong Farao var en ugudelig krop《, 》Der var saa stille ved midjenat«, 》Ved Babylons floder« og den fine, stille Mariavise 》Tidens fylde var nu kommet《. I visetone er endelig ogsaa »Guds ord blev aldrig bundet« fra Aagaards og Rings »30 salmemelodier til Salmebog f. valgmenigheder og frimenigheder« 1936. - Jf. hertil Th. Laub: "Thorvald Aagaards sange« (Højskolebl. 1920, sp. 279) og F. J. Ring: 》Thorv. Aagaard. Et liv i folkesangens tjeneste《 (»Julebogen《 1944, udg. af Kirkel. samf. af 1898 v. Edv. Petersen. Optr. i Danmarks sanglærerforenings aarsberetn. f. 1944, s. 22-33).

Af Oluf Rings Grundtvig-salmer kan anføres »Søde Gud! din engleskare« og 》Trods længselens smerte《 (begge i Larsen, Viderø og Wöldike: 130 melodier« 1936). Hertil »Kom, lad os tømme et bæger paany« og »Ton det, himmel, syng det, jord《 i »30 salmemelodier《 (1936) og »Der ligger en stad i det tyrkiske land (1944) og »At nær ved kirke stander slot《 (1945) i Rings 》15 salmer og folkelige sange《 (tr. posth. 1947). - Mindeartikler om Ring i »Danskeren« sept. 1946, i Danmarks sanglærerforenings aarsberetn. f. 1946 og i Højskolebladet 10.5.1946.

${ }^{79}$ ) Se min bemærkning desangaaende (i forb. m. Aagaard) i artiklen $\gg$ Vor folkesangs 'Fire store'« (»Landet《 13.6.1946). 